\title{
GOVERNADORES E ÍNDIOS, GUERRAS E TERRAS ENTRE O MARANHÃO E O PIAUÍ (PRIMEIRA METADE DO SÉCULO XVIII)'
}

Contato

Rafael Chambouleyron Tv. Quintino Bocaiuva, 1574/1301 66035-190 - Belém - Pará E-mail: rafaelch@ufpa.br

Vanice Siqueira de Melo Rua Gaiapós, 303 66033-840 - Belém - Pará E-mail: vanicesmelo@gmail.com

\section{Rafael Chambouleyron}

Universidade Federal do Pará

Vanice Siqueira de Melo

Mestre em História pela Universidade Federal do Pará

\section{Resumo}

Este artigo examina o processo de expansão portuguesa pelos sertões orientais da capitania do Maranhão e pela capitania do Piauí nas primeiras décadas do século XVIII, procurando explicar as conexões entre as guerras contra os índios daquela região, a expansão do gado e os interesses principalmente dos governadores do Estado do Maranhão e Pará.

\section{Palavras-chave}

Capitania do Maranhão - capitania do Piauí - século XVIII - índios - guerras - gado.

\footnotetext{
${ }^{1}$ Esta pesquisa conta com o apoio do CNPq, da Fapespa e da FCT, no âmbito do projeto PTDC/ HIS-HIS/113654/2009. Os autores pertencem ao grupo de pesquisa "Terra, natureza e território na Amazônia luso-brasileira" da Universidade Federal do Pará, Os autores agradecem as sugestões do parecerista anônimo da revista e de Antonio Otaviano Vieira Jr.
} 


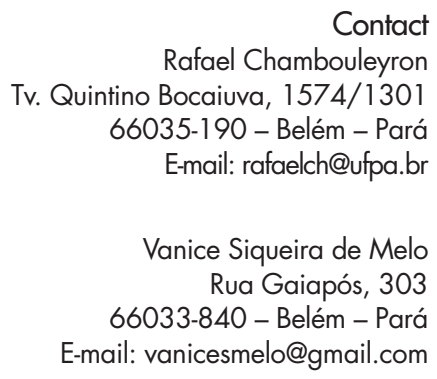

Contact

Rafael Chambouleyron Tv. Quintino Bocaiuva, 1574/1301 66035-190 - Belém - Pará

E-mail: rafaelch@ufpa.br

Vanice Siqueira de Melo Rua Gaiapós, 303 66033-840 - Belém - Pará E-mail: vanicesmelo@gmail.com

\section{GOVERNORS AND \\ INDIANS, WARS AND \\ LANDS BETWEEN \\ MARANHÃO AND \\ PIAUÍ (FIRST HALF \\ OF THE EIGHTEENTH \\ CENTURY)}

\section{Rafael Chambouleyron}

Universidade Federal do Pará

\section{Vanice Siqueira de Melo}

Master's Degree in History - Universidade Federal do Pará

\begin{abstract}
This article examines the Portuguese expansion towards the eastern hinterlands of the captaincies of Maranhão and Piauí, in eighteenth-century Portuguese America. It focuses on the relationship between the many wars against the Indians of this region, the spread of cattle ranching and the personal and political interests of the governors of the State of Maranhão and Pará.
\end{abstract}

\title{
Keywords
}

Captaincy of Maranhão - captaincy of Piauí - eighteenth century - Indians wars - cattle ranching. 
A porção oriental do Estado do Maranhão e Pará que, em princípios do século XVIII, congregava as capitanias do Maranhão e do Piauí teve uma história conturbada durante boa parte do período colonial. Se a sua ocupação começou poucos anos depois da conquista de São Luís aos franceses, o vasto sertão que se espraiava a sudeste dessa cidade foi marcado por recorrentes conflitos contra grupos indígenas que embaraçavam a expansão dos engenhos e dos currais dos portugueses. Região cobiçada pela Coroa, pelas autoridades e moradores, assistiu, em finais do século XVII, a um processo de expansão em direção ao leste precedido de inúmeras guerras contra os índios e sedimentado, em grande medida, por meio da doação de sesmarias, principalmente numa conjuntura de incremento do consumo das carnes, em razão do desenvolvimento das Minas. Este artigo examina esse processo, nas primeiras décadas do século XVIII, procurando conectar as guerras à expansão do gado, mas também aos interesses principalmente dos governadores do Estado.

Trata-se, assim, de entender a relação entre conflitos, gado e governadores a partir de duas questões principais: por um lado, a relação entre guerra e expansão da pecuária (que caracterizou igualmente outras regiões da América portuguesa); por outro lado, o papel dos governadores nesse processo. A indagação que nos fazemos ao analisar esse período é a de pensar em que medida a guerra e a expansão da pecuária na região oriental do Estado do Maranhão e Pará (capitanias do Maranhão e Piauí) acompanhou um movimento contemporâneo que se dava no Estado do Brasil, ou foi também marcado pela ação particular dos governadores do Estado do Maranhão e de seus interesses na região.

\section{Os “alarves" e o "jardim" do Maranhão}

Desde o início do século XVII, os portugueses instalaram engenhos nos rios que deságuam nas baías da ilha de São Luís; um dos primeiros relatos após a ocupação de São Luís e fundação da cidade de Belém, escrito pelo capitão Simão Estácio da Silveira, refere-se aos rios Itapecuru, Mearim, Munim, Pindaré e Maracu como lugares onde se poderia fundar um "reino opulentíssimo". ${ }^{2}$ Esta primeira impressão se manteve ao longo do século XVII e a região passou a ser ocupada principalmente por engenhos cobiçados in-

\footnotetext{
2 SILVEIRA, Simão Estácio da. Relaçaõ Sumaria das cousas do Maranhão. Escripta pello Capitão Symão Estacio da Sylveira. Dirigida aos pobres deste Reyno de Portugal [1624]. Anais da Biblioteca Nacional - (ABN). Rio de Janeiro: Biblioteca Nacional, vol. 94, 1974, p. 113.
} 
clusive pelos holandeses que ocuparam São Luís de 1641 a $1643 .{ }^{3}$ Entretanto, a partir da década de 1650, nas correspondências trocadas entre o Estado e a corte, começam a aparecer inúmeras notícias sobre a ação deletéria dos índios. Já em 1649, os índios Uruati teriam matado quatro religiosos jesuítas estabelecidos no Itapecuru. ${ }^{4}$ Em 1662, o procurador do povo do Maranhão, Jorge de Sampaio e Carvalho, representava na corte que o rio Munim "tem terras e várzeas consideráveis em bonidade para nelas se plantar canas de fazer açúcar". Entretanto, explicava, nada era possível se a região não fosse defendida "dos alarves de que de ordinário é infestado"."

A seriedade da ameaça devia certamente ser pesada em razão das inúmeras notícias que exaltavam os rios do Maranhão. Escrito provavelmente nos anos 1660 ou pouco depois, um texto anônimo que dava uma rápida notícia das povoações do Estado lamentava que, no rio Itapecuru, não havia "mais que um ou dois engenhos, porque se despovoou por medo dos tapuias que o infestavam". ${ }^{6}$ Mais ou menos na mesma época, referindo-se ao Itapecuru, o ouvidor-mor Maurício de Heriarte advertia sobre a ameaça "dos índios do corso, que muitas vezes fazem dano aos engenhos e moradores".7

As "correrias" dos índios preocupavam a Coroa, as autoridades régias no Maranhão e os moradores. Ao longo das primeiras décadas da segunda metade do século XVII, a ação dos índios tinha sido responsável pelo despovoamento da faixa oriental da capitania do Maranhão. Não sem razão, na década de 1680, o capitão Manuel Guedes Aranha declarava que, “jardim que era do Maranhão", o Itapecuru, "para o que já teve e para o que é capaz e desejado, está como despovoado pelas assaltadas e dano que o tapuia do mato por repetidas vezes lhe tem dado". ${ }^{8}$

\footnotetext{
3 MARQUES, Cezar Augusto. Diccionario historico-geographico da provincia do Maranhão. Maranhão: Typ. do Frias, 1870, p. 340; CARDOSO, Alírio Carvalho. Maranhão na Monarquia hispânica: intercâmbios, guerra e navegação nas fronteiras das Índias de Castela (1580-1655). Doutorado, História, Universidad de Salamanca, 2012, p. 269.

4 BETTENDORFF, João Felipe, SJ. Crônica da missão dos padres da Companhia de Jesus no Maranhão. Belém: Secult, 1990 [1698], p. 69.

5 Requerimento dos oficiais da câmara e procuradores do povo da cidade de São Luís. Arquivo Histórico Ultramarino - AHU, Maranhão, 1662, documento 463.

${ }^{6}$ Noticia do Estado do Maranhaõ. Biblioteca da Ajuda, 1660-1670, códice 50-V-37, f. 139.

7 HERIARTE, Maurício de. Descrição do Estado do Maranhão, Pará, Corupá e rio das Amazonas. In: VARNHAGEN, Francisco Adolfo de. História geral do Brasil. Tomo 3. $8^{\mathrm{a}}$ edição. São Paulo: Melhoramentos, 1975, p. 172.

${ }^{8}$ ARANHA, Manuel Guedes. Papel político sobre o Estado do Maranhão. Revista do Instituto Histórico e Geográfico Brasileiro. Rio de Janeiro: IHGB, tomo 46, 1ª parte, [c. 1682] 1883, p. 3.
} 
Nas décadas finais do século XVII, a Coroa passa a se mobilizar para retomar o controle do leste do Estado do Maranhão e Pará. Mas é somente a partir dos anos 1690 que as guerras organizadas pelas autoridades contra os índios hostis tiveram lugar na capitania do Maranhão. A partir do final do século XVII, há um esforço da Coroa em expulsar ou dominar os índios que investiam contra as povoações do leste do Estado do Maranhão e Pará. A primeira dessas guerras aconteceu em 1691. Segundo o padre Bettendorff, "com esta esfrega dada aos Caicai ficou algum tanto, ainda que não de todo, seguro o recôncavo do Maranhão", pois estes índios "não se acovardaram com a diminuição e foram continuando suas hostilidades". 9 Por esta razão, em 1695, foi planejada a realização de outra guerra contra os índios hostis na capitania do Maranhão. ${ }^{10}$

Após a realização das guerras de 1691 e de 1695, entretanto, as queixas dos moradores dos rios Itapecuru, Mearim, Munim e da recém-criada vila de Icatu contra os índios persistiram. Segundo o padre Bettendorff, a investida de 1695 contra os índios serviu "para exacerbar os ânimos daqueles bárbaros e outros como eles contra os brancos". Os índios continuavam "assaltando os escravos e os mesmos brancos, quando se achavam descuidados" e os moradores não iam "para as suas lavouras e canaviais, por medo de alguma morte desastrada".11

Assim, em 1698-1699, novamente o tema da guerra vinha à tona. Em uma petição escrita por seu procurador, os moradores da capitania do Maranhão insistiam que a capitania "depende totalmente de povoarem-se os rios do Itapecuru e Mearim, e de se povoarem as suas terras", o que não podia ser feito em razão dos "contínuos assaltos do gentio do corso".12 Em carta de julho de 1699, o próprio governador, Antônio de Albuquerque Coelho de Carvalho, reconhecia que as correrias dos índios causavam graves transtornos às lavouras. ${ }^{13}$ Contudo, a guerra, deflagrada pelo sucessor de Coelho de Carvalho, o loco-tenente Fernão Carrilho (1701-1702, participante das expedições contra Palmares e depois capitão-mor do Ceará), deixou dúvidas sobre a sua legitimidade em razão dos excessos praticados pelas tropas.

\footnotetext{
9 BETTENDORFF, João Felipe, SJ., op. cit., p. 517.

${ }^{10} \mathrm{CCU}, 26 / 01 / 1696$, AHU, Maranhão, documento 912.

11 BETTENDORFF, João Felipe, SJ, op. cit., p. 558.

12 A petição encontra-se anexada em: CCU, 21/02/1699, AHU, Maranhão, documento 977.

13 A carta do governador do Maranhão para o rei escrita na cidade de Belém, em 24/07/1699, encontra-se anexada em: CCU, 14/10/1699, AHU, Pará, documento 356.
} 
A ação de Fernão Carrilho (e não só ela) levou a Coroa a reconsiderar o lugar das guerras e suas implicações. Não há dúvida de que as guerras da última década do século XVII parecem estar atreladas a uma política mais geral, de há tempos consolidada, cujo sentido era a retomada da porção leste da capitania do Maranhão, como mencionamos acima, movimento contemporâneo à tomada dos sertões das capitanias do norte do Estado do Brasil. A esse interesse da Coroa, levado a cabo pelas autoridades régias, soma-se uma conjuntura específica do Estado do Maranhão e Pará, que foi o agravamento dos problemas de mão-de-obra, decorrentes da irrupção de uma grave epidemia de bexigas, entre 1695 e $1696 .{ }^{14}$ Assim, os conflitos da virada do século XVII para o XVIII têm uma natureza tanto de aquisição de escravos como de domínio territorial e garantia dos territórios de produção da capitania do Maranhão, problemas que para as autoridades e moradores do Estado do Maranhão e Pará não eram excludentes. ${ }^{15}$ Por outro lado, o aumento das guerras contra os índios, desde finais do século XVII, ensejou por parte da Coroa um incremento nos próprios mecanismos de controle sobre os conflitos. Como aponta Márcia Mello, a investigação sobre a legitimidade das causas das guerras esteve marcada pela implantação efetiva das Juntas das Missões no Estado do Maranhão e Pará. ${ }^{16}$

Mas a ação de Fernão Carrilho (pessoalmente implicado nos circuitos de escravização indígena que se estendiam até o Pará) ${ }_{17}^{17}$ condenada pelas autoridades, permite entrever o avigoramento de uma figura - a do governador - que terá um papel cada vez mais importante na deflagração dos conflitos ao longo das primeiras décadas do século XVIII, paralelamente, nesse con-

\footnotetext{
${ }^{14}$ CHAMBOULEYRON, Rafael, BARBOSA, Benedito Costa, BOMBARDI, Fernanda Aires e SOUSA. Claudia Rocha de. "Formidável contágio". Epidemias, trabalho e recrutamento na Amazônia colonial (1660-1750). História, Ciências, Saúde - Manguinhos. Rio de Janeiro: Casa Oswaldo Cruz, v. 18, n. 4, 2011, p. 987-1004.

${ }^{15}$ Tratamos desta questão em texto voltado fundamentalmente para o século XVII. Ver: CHAMBOULEYRON, Rafael e MELO, Vanice Siqueira de. Índios, engenhos e currais na fronteira oriental do Estado do Maranhão e Pará (século XVII). In: MOTTA, Márcia; SERRÃO, José Vicente e MACHADO, Marina (orgs.). Em terras lusas: conflitos e fronteiras no Império português. Guarapuava/ Niterói: Unicentro/EdUFF, 2012, p. 236-64.

${ }^{16}$ MELLO, Marcia Eliane Alves de Souza e. Fée Império: as Juntas das Missões na conquista portuguesa. Manaus: EdUFMA, 2009, p. 162-63 e 317.

17 Sobre Fernão Carrilho, ver: SANTOS, Fabiano Vilaça dos. Feitos de armas e efeitos de recompensa: perfil do sertanista Fernão Carrilho. Klepsidra, no 19, 2004. Disponível em http://www. klepsidra.net/klepsidra19/fernaocarrilho.htm. Acesso em 2/03/2011. MELLO, Marcia Eliane Alves de Souza e, op. cit., p. 307-309.
} 
texto, à política mais geral da Coroa com relação aos índios do Estado do Maranhão e Pará. ${ }^{18}$

As ações dos governadores Cristóvão da Costa Freire (1707-1718) e Bernardo Pereira de Berredo (1718-1722), queremos crer, indicam o papel central que os governadores adquirem no contexto geral do Estado do Maranhão e Pará. Há, desde o século XVII, um gradativo processo de centralização das políticas régias para a região que terá nos governadores - em geral apoiados pelos moradores - um instrumento fundamental. ${ }^{19}$ Ora, justamente os conflitos com diversos grupos indígenas nas primeiras décadas do século XVIII, bem como a relativa paz estabelecida no início dos anos 1720, quando João da Maia da Gama (1722-1728) assume o governo, revelam indícios de que a ação dos governadores na expansão pelos sertões orientais do Estado parecia estar talvez mais atrelada aos interesses que construíam na conquista, do que a uma política mais geral orquestrada pela Coroa, muito embora a corte tenha, em diversos momentos, abalizado e garantido as ações levadas a cabo pelas autoridades régias.

\section{Guerras e pecuária}

Um dos principais vetores da expansão portuguesa nas capitanias do Maranhão e do Piauí foi a criação de gado. A partir do século XVII, o desenvolvimento desta atividade modificou a paisagem de diversas áreas do interior. Extensas regiões da América portuguesa dominadas por milhares de índios transformaram-se em importantes áreas criatórias, fundamentais para o abastecimento de carne em outras regiões da colônia.

As inúmeras guerras contra os índios que aconteceram no interior da região hoje denominada de nordeste, a partir da segunda metade do século XVII, são associadas à interiorização pecuária na América portuguesa. Essas interpretações articulam o avanço da criação de gado e as guerras contra os

\footnotetext{
${ }^{18}$ Essa política tinha se definido, em linhas gerais, nas últimas décadas do século XVII, com o Regimento das Missões (1686), a permissão dos resgates e guerra justa (1688) e com a divisão dos distritos missionários entre as ordens religiosas (1693). Para uma discussão recente sobre este período, ver: GUZMÁN, Décio de Alencar. A colonização nas Amazônias: guerras, comércio e escravidão nos séculos XVII e XVIII. Revista Estudos Amazônicos. Belém: UFPA, vol. III, nº 2 , 2008, p. 103-39; DIAS, Camila Loureiro. Civilidade, cultura e comércio: os princípios fundamentais da política indigenista na Amazônia (1614-1757). Dissertação de mestrado, História, USP, 2009, p. 49-86; MELLO, Marcia Eliane Alves de Souza e, op. cit., p. 243-317.

${ }^{19}$ Ver: CHAMBOULEYRON, Rafael. Povoamento, ocupação e agricultura na Amazônia colonial (1640-1706). Belém: Açaí/PPHIST/CMA, 2010.
} 
grupos indígenas à necessidade de expansão da conquista territorial portuguesa. A historiografia que trata da interiorização portuguesa por meio da pecuária, no interior do hoje nordeste, frequentemente enfatiza as condições naturais e os problemas decorrentes da criação de gado e desenvolvimento da agricultura e da plantação da cana na mesma região como justificativa para a expansão portuguesa para as áreas interioranas.

Capistrano de Abreu, por exemplo, atribui às regiões impróprias ao cultivo da cana qualidades para o desenvolvimento da criação de gado. Além disso, atribui às hostilidades dos índios a justificativa para os conflitos. Segundo Capistrano de Abreu, as margens do rio São Francisco, onde se localizavam inúmeras fazendas de gado, eram habitadas por numerosos grupos indígenas. A recusa destes índios em ceder pacificamente as terras dessa região para a expansão da pecuária e as tentativas de usufruírem do gado determinou a realização das guerras contra eles. ${ }^{20}$

No mesmo sentido, para José Alípio Goulart, o processo de interiorização teria sido dificultado pela presença dos holandeses em diversas regiões interiores do nordeste e pela "indiada revoltada", comprimida pelo avanço do gado. As guerras movidas contra esses dois grupos teriam sido fundamentais para o desenvolvimento da pecuária, pois elas tiveram o mérito de devassar "quase completo o interior nordestino", favorecendo um expansionismo da pecuária. ${ }^{21}$

A articulação entre o desenvolvimento da pecuária e os conflitos com os índios é evidente nas discussões de Odilon Nunes acerca da ocupação portuguesa no Piauí. Para Nunes, os conflitos com os índios na segunda metade do século XVII consistem na "luta pelo domínio da terra": era a luta dos criadores de gado contra os grupos indígenas que vivenciavam um processo de espoliação das suas terras. No século XVIII, o combate pela terra é permeado por outros aspectos, pois já seria um conflito entre sesmeiros e posseiros.22

Nesse sentido, a expansão portuguesa pelo interior do nordeste foi interpretada pela historiografia como um movimento que ocorreu "sob o signo da violência e repressão" aos grupos indígenas. Maria do Socorro Cabral

\footnotetext{
${ }^{20}$ ABREU, João Capistrano de. Capítulos de história colonial. Brasília: Conselho Editorial do Senado Federal, 1998, p. 133.

${ }^{21}$ GOULART, José Alípio. O Brasil do boi e do couro. Rio de Janeiro: Edições GDR, 1965, vol. 1, p. 26-28.

22 NUNES, Odilon. Pesquisas para história do Piauí. Teresina: Imprensa Oficial, 1966, vol. I, p. 63-105. Sobre a ocupação do Maranhão e Piauí na segunda metade do século XVIII, ver: BRANDÃO, Tanya Maria Pires. A elite colonial piauiense: família e poder. Teresina: Fundação Cultural Monsenhor Chaves, 1995; e MOTA, Antonia da Silva. As famílias principais: redes de poder no Maranhão colonial. São Luís: EdUFMA, 2012.
} 
lembra que a violência contra os indígenas do Maranhão esteve presente no litoral e no sul maranhense. ${ }^{23}$ Já Francisco José Pinheiro associa o aumento da doação de sesmarias à intensificação dos conflitos contra os grupos indígenas no Ceará; para ele o conflito foi se "agudizando" à medida que as terras iam sendo ocupadas, principalmente nas duas primeiras décadas do século XVIII. ${ }^{24}$ Como defendeu Luiz Mott, "a violência foi a tônica do contato interétnico. A violência é que foi o modus vivendi desta sociedade". ${ }^{25}$ Assim, inúmeras vezes os grupos indígenas são compreendidos como vítimas do avanço da fronteira luso-brasileira pelo Maranhão e pelo Piauí, apesar das inúmeras resistências oferecidas por eles. Nesse sentido, Luiz Felipe de Alencastro, ao abordar a chamada Guerra dos Bárbaros, considera que, se a implantação do tráfico negreiro e a ação dos missionários ajudaram a preservar os índios, logo os nativos se tornaram um obstáculo à "expansão da fronteira agropastoril", razão pela qual passaram a ser dizimados. ${ }^{26}$

Pedro Puntoni analisou os conflitos contra os índios que aconteceram no interior do nordeste durante o século XVII como uma política do governo português com relação aos índios que eram considerados empecilho à expansão e desenvolvimento da pecuária na região, constituindo uma "ampla e duradoura muralha que se erguia no sertão". Puntoni argumenta que essas guerras representavam um novo padrão de relacionamento do Império português com as populações indígenas, pois, diferentemente das guerras ocorridas no século XVI que objetivavam submeter os índios, as guerras no século XVII pretendiam aniquilar as populações indígenas. ${ }^{27}$

De um modo em geral, as reflexões sobre a interiorização portuguesa, portanto, associam o avanço da pecuária ao surgimento dos conflitos com os índios, em grande medida, como um movimento de causa e efeito. ${ }^{28} \mathrm{~A}$

${ }^{23}$ CABRAL, Maria do Socorro Coelho. Caminhos do gado: conquista e ocupação do sul do Maranhão. São Luís, SIOGE, 1992, p. 64-133.

${ }^{24}$ PINHEIRO, Francisco José. Mundos em confronto: povos nativos e europeus na disputa pelo território. In: SOUSA, Simone de (org.). Uma nova história do Ceará. $2^{a}$ edição. Fortaleza: Edições Demócrito Rocha, 2002, p. 27-37.

${ }^{25}$ MOTT, Luiz. Piauí colonial. População, economia e sociedade. Teresina: Projeto Petrônio Portella, 1985, p. 131.

${ }^{26}$ ALENCASTRO, Luiz Felipe de. O trato dos viventes. Formação do Brasil no Attântico sul. São Paulo: Companhia das Letras, 2000, p. 337.

${ }^{27}$ PUNTONI. A guerra dos Bárbaros. Povos indígenas e a colonização do sertão nordeste do Brasil, 1650-1720. São Paulo: Hucitec/EdUSP, 2002, p. 17, 45-46.

${ }^{28}$ Para Cristina Pompa, entretanto, os conflitos na segunda metade do século XVII no nordeste colonial foram "muito mais do que guerra de extermínio para permitir o avanço da frente pastoril". Para ela, houve contínuas rearticulações de "relações econômicas e de poder", com 
expansão portuguesa na região seria determinante para o surgimento das guerras contra os índios. Assim, poderíamos dizer que essas interpretações naturalizam o desenvolvimento da pecuária e a emergência dos conflitos, pois compreendem que as guerras contra os índios são inevitáveis diante do imperioso expansionismo português sobre suas terras.

Os conflitos com os grupos indígenas foram analisados pela historiografia como uma política da Coroa portuguesa aplicada aos índios hostis na América portuguesa. Por essa razão, estariam associados somente ao desenvolvimento das atividades econômicas na expansão do povoamento lusitano. Ou seja, as guerras estavam articuladas às necessidades de expansão e dominação territorial portuguesa. Dessa maneira, as guerras são compreendidas como mecanismos de conquista territorial e de escravização dos grupos indígenas.

Nesse contexto, a partir da experiência oriental do Estado do Maranhão e Pará, argumentamos aqui que, para além dessa relação entre expansionismo e conflito, inserida numa política mais geral da Coroa para a América portuguesa, as guerras contra os índios são também determinadas por interesses construídos localmente, principalmente por parte dos governadores que, no Estado do Maranhão e Pará, desde o século XVII, tiveram um papel fundamental para a organização da conquista, mesmo depois de acabados os seus governos. ${ }^{29}$ Nesse sentido, acreditamos que as guerras contra os índios e a paz alcançada com eles não se explicam somente por determinações mais globais tanto da política indigenista portuguesa quanto da política de expansão do gado emanadas da Coroa. Há um componente de interesses pessoais e de conflitos internos que ajuda a entender o significado desses eventos no contexto específico do Estado do Maranhão e Pará. Desta maneira, no Estado do Maranhão e Pará, as guerras estavam igualmente associadas a diversos negócios construídos localmente. Os embates que se seguiram à deflagração de diversas guerras no leste do Estado nos governos de Cristóvão da Costa Freire e de Bernardo Pereira de Berredo e a relativa paz que se seguiu no governo de João Maia da Gama fornecem indícios dessas complexas relações.

\footnotetext{
avanços e recuos, em que os índios "não exerceram apenas o papel de vítimas mudas ou de protagonistas de uma cega quanto inútil 'resistência'", procurando inserir-se nas contingências históricas em função de seus próprios interesses. POMPA, Cristina. Religião como tradução: missionários, Tupi e "Tapuia" no Brasil colonial. Bauru: EdUSC, 2003, p. 218.

${ }^{29}$ O caso mais notável é dos governadores Gomes Freire de Andrade e Antônio de Albuquerque Coelho de Carvalho (finais do século XVII e princípios do século XVIII) que, mesmo depois de terminados seus mandatos, eram frequentemente ouvidos no Conselho Ultramarino e, em grande medida, foram responsáveis por ditar as políticas da Coroa para a conquista do Maranhão e Pará.
} 


\section{“Grandes danos e hostilidades": Cristóvão da Costa Freire}

Nas primeiras décadas do século XVIII, as guerras na porção oriental do Estado continuaram. Em 1704, o governador d. Manuel Rolim de Moura (1702-1705) respondia aos oficiais da Câmara de São Luís sobre uma guerra ao gentio do corso solicitada pelos vereadores, afirmando de sua parte não terem faltado escoltas e diligências contra os índios hostis..$^{30}$ Mas é durante o governo de Cristóvão da Costa Freire que os conflitos se acirram. De fato, no início do século XVIII, a capitania do Piauí, cuja primeira ocupação esteve marcada pela participação de gentes da Bahia e Pernambuco, se incorpora à jurisdição do Estado do Maranhão e Pará. ${ }^{31}$ Esse processo, no fundo, permitia aos representantes da Coroa no Estado do Maranhão e Pará também a extensão da sua influência política, que se expressava por meio das relações que estabeleciam com grupos locais, já estabelecidos na região ou em São Luís, ou indivíduos vindos do além-mar; a guerra podia representar aqui um interessante mecanismo de construção de redes de influência para os governadores.

Assim, logo no início de seu governo, Costa Freire escrevia ao monarca informando sobre os "grandes danos e hostilidades que o gentio do corso tem feito todos esses anos aos moradores dos rios Mearim, Munim e Itapecuru", como referia uma consulta do Conselho Ultramarino. Diante da situação, o próprio Conselho considerava que era "justíssima a guerra que se assentou em Junta que se convocaram no mesmo Estado" para "se evitar tantos insultos quanto cometiam estes índios". ${ }^{32}$ Em outubro do mesmo ano, d. João V escrevia ao governador autorizando a guerra e acrescentava ainda que a fizesse "cruamente ao tal gentio". Além disso, recomendava também

\footnotetext{
${ }^{30}$ Senhores officiais da Camara. Pará, 28/04/1704. Arquivo Público do Estado do Maranhão Apem, livro de correspondência (1696-1798), ff. 30-31.

${ }^{31}$ Sobre o processo de ocupação do Piauí a partir de finais do século XVII, ver: ALENCASTRE, José Martins Pereira de. Memória cronológica, histórica e corográfica da província do Piauí. Revista do Instituto Histórico e Geográfico Brasileiro. Rio de Janeiro: IHGB, tomo 20, [1857], p. 14-22; COSTA, Francisco Augusto Pereira da. Cronologia histórica do Estado do Piauí. $2^{\mathrm{a}}$ edição. Rio de Janeiro: Editora Artenova, 1974 [1909], p. 42-67; LIMA SOBRINHO, Barbosa. O devassamento do Piauí. São Paulo: Companhia Editora Nacional, 1946, p. 41-73; GOULART, José Alípio. O Brasil do boi e do couro. Rio de Janeiro: Edições GDR, 1965, vol. 1, p. 17-28; NUNES, Odilon, op. cit., p. 63-105. Sobre a incorporação do Piauí à jurisdição do Estado do Maranhão e Pará, ver: GALINDO, Marcos. Governo das almas: A expansão colonial no país dos tapuia. 1651-1798. Tese de doutorado, História, Universiteit Leiden, 2004, p. 240-244.

32 O governador do Maranhaõ da conta dos gr. ${ }^{\text {des }}$ danos, e hostilidades. 12/10/1707. AHU, códice 274, ff. 186-186v.
} 
ao governador que escrevesse a Antonio da Cunha Souto Maior, que vivia no Piauí, ${ }^{33}$ para que fosse ao Maranhão "com toda a gente que puder agregar a si para se incorporar com a tropa que haver de expedir da capitania do Maranhão", dando a ele 60 soldados. ${ }^{34}$

O mestre de campo Antonio da Cunha Souto Maior combateu os índios hostis na região oriental do Maranhão até o ano de 1712, quando foi assassinado por um grupo de índios que também roubaram os apetrechos de guerra, causando muitas destruições pelas povoações da região. ${ }^{35}$ Tratava-se do "levantamento geral dos tapuias do norte", capitaneados por Mandu Ladino, como lembrou José Maria Pereira de Alencastre. ${ }^{36}$

Após o assassinato do mestre de campo, o governador do Maranhão concedeu o posto ocupado a Bernardo Carvalho de Aguiar. Essa concessão de patente a Carvalho de Aguiar foi criticada pelo procurador da Coroa e pelo Conselho Ultramarino. Acreditava o procurador da Coroa que "as razões em que se fundou" o governador para nomear o novo mestre de campo não eram "bastante suficientes". Para o Conselho Ultramarino, o governador deveria somente "encomendar o mando da tropa de guerra sem lhe dar patente de posto certo e determinado". Porém, "atendendo ao préstimo" de Bernardo Carvalho de Aguiar e a "utilidade que se pode seguir da continuação da guerra", acreditava o conselho que o rei deveria passar a patente do posto de mestre de campo a Carvalho de Aguiar. ${ }^{37}$

A concessão arbitrária da patente de mestre de campo a Bernardo Carvalho de Aguiar por Costa Freire sugere que este governador tinha interesses na participação de Carvalho de Aguiar nas tropas de guerras enviadas contra os índios hostis. Embora fosse reconhecido o "préstimo" de Bernardo Carvalho de Aguiar, a nomeação dele era uma tentativa de satisfazer aos interesses do governador, ampliando suas alianças, e do mestre de campo.

\footnotetext{
33 Uma eleição que reuniu os moradores do sertão do Piauí, em 1697, menciona seu nome. Ver: Termo da eleição q. ${ }^{e}$ fizerão os moradores do certão do Piauhi, do lugar, p. ${ }^{a}$ se fazer a Ig. ${ }^{\text {ja }}$ de Nossa Senhora da Victoria. 11/02/1697. In: ENNES, Ernesto. As guerras nos Palmares. São Paulo: Companhia Editora Nacional, 1938, p. 364-65.

${ }^{34}$ Para o governador geral do Maranhão, 25/10/1707. ABN, Rio de Janeiro: Biblioteca Nacional, vol. 67, 1948, p. 15-17.

${ }^{35} \mathrm{O}$ gov. ${ }^{\text {or }}$ do estado do Maranhaõ da conta das mortes, roubos e extroçoens. 14/11/1713. AHU, códice 274, ff. $232 \mathrm{v}-234$.

${ }^{36}$ ALENCASTRE, José Martins Pereira de, op. cit., p. 26-27. Sobre o levante, ver também: HEMMING, John. Red gold: the conquest of the Brazilian Indians. Londres: Papermac, 1995, p. 379-80.

${ }^{37} \mathrm{O}$ gov. ${ }^{\text {or }}$ do estado do Maranhaõ da conta das mortes, roubos e extroçoens. 14/11/1713. AHU, códice 274 , ff. $232 \mathrm{v}-234$.
} 
Nos anos seguintes, o governador enviou inúmeras vezes Bernardo Carvalho de Aguiar ao sertão para combater os índios hostis. Após guerrear contra os índios que teriam assassinado o mestre de campo Antonio da Cunha Souto Maior, Bernardo Carvalho de Aguiar foi chamado em 1714 pelo governador para realizar outra guerra. O governador Cristóvão da Costa Freire afirmava que, nesse ano, tivera noticias "das mortandades estragos e hostilidades que fazia o gentio do corso na Parnaíba". Assim, ordenara ao mestre de campo Carvalho de Aguiar que fizesse uma "cruenta guerra" contra os índios. ${ }^{38}$ Nesse mesmo período, os moradores dos rios Itapecuru, Mearim e Munim também eram alvos de investidas dos índios Barbados. Assim, em 1715, o governador Cristóvão da Costa Freire foi, pessoalmente, fazer guerra aos Barbados e teria avisado ao mestre de campo Bernardo Carvalho de Aguiar e ao sargento-mor Miguel de Abreu Sepúlveda que se unissem a ele e à tropa de São Luís nas Aldeias Altas, onde os esperou em vão por um mês. ${ }^{39}$

O sucessor de Cristóvão da Costa Freire no governo do Maranhão, Bernardo Pereira de Berredo, não mantinha alianças com o mestre de campo Bernardo Carvalho de Aguiar. O próprio Carvalho de Aguiar escreveu ao Conselho Ultramarino censurando a postura do governador Pereira de Berredo, como veremos. Além disso, os oficiais da Câmara de São Luis, aliados políticos do Bernardo Pereira de Berredo, escreveram ao rei d. João V, em julho de 1721, criticando a atuação do mestre de campo Carvalho de Aguiar que teria deixado de combater os índios, voltando para suas fazendas, o que aumentava ainda mais "as ruínas e consideráveis perdas nestes pobres moradores". ${ }^{40}$

Outro indício das conexões entre as guerras e os interesses dos governadores era a participação do sargento-mor Francisco Cavalcanti. Desta vez, era o provedor-mor da Fazenda Vicente Leite Ripado que, em julho de 1718, se queixava da atuação de Cavalcanti nas expedições ao sertão, quando, em 1716, fora enviado por Costa Freire a combater os índios do corso. ${ }^{41}$ Segundo Leite Ripado, havia "pública queixa" de que Francisco Cavalcanti, passando pela povoação dos Longá, "havia roubado os moradores dela", invadindo "as casas como salteador público com alguns de sua comitiva". Além disso, soldados do presídio do Iguará teriam presenciado "furtos e descaminhos"

\footnotetext{
38 A carta de Cristóvão da Costa Freire, escrita em São Luís, em 14/04/1716, está anexada em: CCU. 6/10/1718, AHU, Maranhão, documento 1199.

39 Carta de Cristóvão da Costa Freire. Belém, 11 de junho de 1716. AHU, Pará, documento 519.

${ }^{40}$ Carta dos oficiais da Câmara de São Luís. São Luis, 18/07/1721. AHU, Maranhão, documento 1310.

${ }^{41}$ Ver: Ordem em forma de regim. ${ }^{\text {to }} \mathrm{q}$. leva o mestre de campo da conquista Bernardo de Carv. ${ }^{\circ} \mathrm{e}$ Aguiar. São Luis, 29/10/1716. Anexado em: CCU, 6/10/1718, AHU, Maranhão, documento 1199.
} 
nas "munições, mantimentos e mais petrechos e provisões da dita tropa". Esses crimes já haviam sido praticados antes por Cavalcanti, segundo o ouvidor, não se atrevendo a denunciá-lo os soldados por "respeito e temor do governador e capitão geral", de quem era "feitura e muito favorecido o dito cabo Francisco Cavalcanti". ${ }^{22}$ Diferentemente do que acontecia com Carvalho de Aguiar, Francisco Cavalcanti também soubera conquistar a "estima" do sucessor de Costa Freire, correndo Leite Ripado riscos se ousasse prendê-lo, dados os favores dos governadores. ${ }^{43}$

As queixas do provedor-mor sobre os procedimentos do sargento Francisco Cavalcante devem ser compreendidas a partir dos conflitos existentes entre os membros da burocracia colonial. Como lembrou David Feio para o caso do Estado do Maranhão e Pará, os governadores teriam menos conflitos com os oficiais da câmara do que com os ouvidores e provedores. O provedor da Fazenda, Vicente Leite Ripado, era acerbo opositor dos governadores Cristóvão da Costa Freire e Bernardo Pereira de Berredo. ${ }^{44}$ Já Francisco Cavalcanti, por sua vez, estava inserido nas redes de poder e influência existentes no Estado do Maranhão. ${ }^{45}$

\section{“Atrevidos e insolentes": Bernardo Pereira de Berredo}

Em 1718, Pereira de Berredo assume o posto de governador do Maranhão. No ano seguinte, fazia guerra aos índios Guanaré. Segundo o próprio Berredo, em agosto de 1719, chegava a São Luís, depois de uma temporada no Pará, e pretendia ir logo à "campanha que determinava fazer na capitania do Piauí". Segundo Berredo, os "atrevidos e insolentes", os "tapuias de corso da nação Guanaré", trazendo "outras várias da mesma natureza debaixo de seu nome", pediram um missionário ao governador, que destacou o padre João de Avelar, e acabaram matando-o "aleivosamente" junto com outros índios, ferindo outro religioso e o capitão-mor do Itapecuru. ${ }^{46}$

\footnotetext{
${ }^{42}$ Carta de Vicente Leite Ripado. São Luis, 10/07/1718. AHU, Maranhão, documento 1198.

${ }^{43}$ Carta de Vicente Leite Ripado. São Luis, 13/07/1720. AHU, Maranhão, documento 1252.

${ }^{44}$ Sobre as relações entre os governadores e os provedores da Fazenda, ver: FEIO, David Salomão Silva. As câmaras municipais: administração, elites e exercício do poder local na Amazônia colonial (17071722). Monografia de graduação, História, Faculdade de História, UFPA, 2007, p. 51-66.

${ }^{45}$ DIAS, JoelSantos. Os"verdadeirosconservadores" doEstadodo Maranhão:poderlocal, redesdeclientelaeculturapolítica na Amazônia colonial (primeira metade do século XVIII). Dissertação de mestrado, História, UFPA, 2008, p. 249.

${ }^{46}$ A carta de Bernardo Pereira de Berredo escrita em São Luís a 20/03/1720 está anexada em: CCU, 5/03/1721. AHU, Maranhão, documento 1296.
} 
O governador do Maranhão resolveu, assim, "fazer cruelmente a guerra pelo mesmo rio seguindo a sua estrada até as aldeias dos Barbados que foram os principais sócios neste bárbaro insulto". Saiu da cidade de São Luís no dia 16 de setembro de 1719, com 230 soldados pagos e outros tantos índios, fazendo um "destacamento das melhores tropas" no Peritoró, ficando ali "entrincheirado" com mais de 20 soldados e mais índios "dos que não tinham préstimo para a guerra no mato". ${ }^{47}$ Os demais soldados foram à procura dos índios que acabaram percebendo sua aproximação "pela desgraça de disparar-se uma arma". ${ }^{48}$ A refrega, contudo, teve lugar matando-se muitos índios e outros fugindo "embrenhando-se nas matas virgens, como sempre costumam". A tropa continuou pelo rio Mearim, batendo o "gentio do corso" que o "infestava", recolhendo-se a São Luís, "passados três meses e meio de campanha com a importante presa de duzentos e trinta tapuias". ${ }^{49}$

Os oficiais da Câmara de São Luís, que mantinham estreitos laços políticos com Bernardo Pereira de Berredo, elogiaram a sua ação. O próprio Berredo escrevera à câmara pouco antes da campanha, oferecendo-se "na defesa das suas fazendas e segurança das suas vidas" não "só na ocasião da próxima campanha, mas em todas as mais que para conseguir este glorioso fim me parecer preciso". ${ }^{50}$ Segundo os oficiais de São Luís, Bernardo Pereira de Berredo "sem atender aos inconvenientes de uma trabalhosa jornada se abalou da cidade do Pará a vir para esta do Maranhão" para "libertar" a capitania "das violências e opressões do gentio bárbaro que a infestava". ${ }^{51}$

\footnotetext{
47 Anos antes, em 1692, o ouvidor-geral do Estado, Miguel da Rosa Pimentel, chamava a atenção para as singularidades da guerra do mato: "e andam tão destros os índios e mamelucos neste emprego que o não têm por danoso, o que é para os soldados do reino pela falta da criação dos matos, e só têm serventia para o presídio das fortalezas". Informaçaõ do Estado do Maranhaõ. Lisboa, 4/09/1692. Biblioteca da Ajuda, códice 50-V-34, nº 43, f. 201. A respeito das peculiaridades da "guerra brasílica", ver: PUNTONI, Pedro. A arte da guerra no Brasil. Tecnologia e estratégia militar na expansão da fronteira da América portuguesa, 1550-1700. Novos Estudos Cebrap. São Paulo: Cebrap, n. 53, 1999, p. 189-204.

${ }^{48}$ Curiosamente e em contradição com o que escreve o governador Berredo em carta ao rei, este mesmo episódio é narrado em seus Annaes como tendo ocorrido a Cristóvão da Costa Freire. Berredo chega a citar que João Nogueira de Sousa teria sido escolhido como cabo da tropa, algo que a ele se lhe imputa. Ver: BERREDO, Bernardo Pereira de. Annaes historicos do Estado do Maranhaõ. Lisboa: Na Officina de Francisco Luiz Ameno, 1749, p. 676.

${ }^{49}$ CCU, 5/03/1721. AHU, Maranhão, documento 1296.

${ }^{50}$ Snr. ${ }^{\text {s }}$ officiaês do Senado da Camr. ${ }^{\text {a }}$ desta cid.e. São Luís, 29/08/1719. Apem, livro de correspondência (1696-1798), f. 77.

${ }^{51}$ Carta dos oficiais da Câmara de São Luís. São Luís, 28/05/1720. AHU, Maranhão, documento 1238.
} 
Entretanto, não foram todas as autoridades, que exaltaram a guerra realizada pelo governador Pereira de Berredo. ${ }^{52}$ Um deles foi Vicente Leite Ripado, ouvidor-mor, provedor da Fazenda e desafeto da Câmara de São Luís e do governador Bernardo Pereira de Berredo, como já mencionamos. ${ }^{53}$ Segundo consulta do Conselho Ultramarino, Vicente Leite Ripado queixava-se do "injusto procedimento" de Berredo em seu governo, "principalmente no que obrou na guerra que fez aos referidos tapuias" provendo em postos "pessoas indignas de os ocuparem, por respeitos particulares". ${ }^{54}$ Em 1720, Leite Ripado escreveu a sua versão de como a guerra contra os Guanaré fora realizada. Segundo ele, de fato, os índios, "com nome fingido de Guanaré", tinham pedido as pazes e missionário, oferecendo-se ainda para ajudar os portugueses na guerra contra os Barbados. Diante disso, Berredo teria tentado aldeá-los, valendo-se do padre João de Avelar que acreditava que os índios eram mesmo Guanaré. Indo com o grupo, o religioso acabou sendo morto. ${ }^{55}$ Com a morte do religioso, o governador teria convocado uma junta que opinara "não haver bastante poder e o dito gentio ser muito numeroso e destemido e estar de aviso pelo caso antecedente"; mais ainda, havia poucos "índios de guerra". Entretanto, o governador decidiu prosseguir com a guerra, acompanhando o voto de João Nogueira, escolhido justamente como cabo da tropa, e culpado numa devassa. Outro criminoso que compunha a tropa, denunciado pelo ouvidor, era Sebastião Rodrigues que cumpria pena de degredo. ${ }^{56}$

Segundo Leite Ripado, uma vez instalado no Peritoró, o governador enviou a tropa, cujas intenções fracassaram, como vimos, pois o disparo de uma arma acabou avisando os índios. Furioso com o fracasso da tropa, o governador mandou que "partissem logo para o Mearim por terra até encontrarem outro qualquer gentio". Transcorridos dois meses, a tropa encontrou uma aldeia na qual foram "recebidos e estiveram com capa de paz". Entretanto, depois de três dias "debaixo da mesma paz", a tropa fez guerra aos índios "matando a uns e aprisionando aos outros, tomando por pretexto que o dito gentio queria levantar-se contra eles". Em seguida, foi a tropa a uma segunda aldeia "ainda com maior hostilidade e mortandade os cativaram e

\footnotetext{
${ }_{52}$ A esse respeito, ver: MEIRELES, Mário M. História do Maranhão. São Paulo: Siciliano, 2001, p. 144.

53 A esse respeito, ver: BERREDO, Bernardo Pereira de, op. cit., p. 681; MARQUES, Cezar Augusto, op. cit., p. 266-68; LIMA, Carlos de. História do Maranhão. $2^{\mathrm{a}}$ edição revista e ampliada. São Luís: Instituto Geia, 2006, p. 424-25; FEIO, David Salomão Silva, op. cit.; DIAS, Joel Santos, op. cit., p. 140-74.

${ }^{54}$ CCU. 5/03/1721. AHU, Maranhão, documento 1296.

${ }^{55}$ Carta de Vicente Leite Ripado. São Luís, 13/06/1720. AHU, Maranhão, documento 1252.

${ }^{56}$ Idem.
} 
se recolheram com 240 presas, fora outras que pelo caminho faleceram". Na cidade de São Luís, os cativos seriam examinados pela Junta das Missões, onde se constatou que eram "de língua geral a quem chamam Guajajaras, aldeados e de paz", não constando que tivessem feito alguma hostilidade, razão pela qual, argumentava o ouvidor, "se não deviam reputar por gentio do corso" nem havia razões para "se julgar por justa a guerra"..$^{57}$

Quanto às presas de guerra, se tiraram os quintos para a Fazenda real e o governador tirou para si de "joia" vinte e quatro índios justificando que "como general lhe tocavam dez por cento, e dois por cento, como cabo da tropa". O cabo João Nogueira levou quatro peças por joia "e os mais a este respeito fazendo também repartição por alguns seus afilhados e aos soldados" e aos "índios forros deu alguma coisa limitada em dinheiro do procedido do mesmo gentio que se vendeu em praça pública". Vicente Leite Ripado queixava-se ainda do excesso dos gastos que a tropa teria importado. ${ }^{58}$

O mestre de campo Bernardo Carvalho de Aguiar, favorecido de Cristóvão da Costa Freire, antecessor de Berredo, também censurou a atuação do governador. Segundo consulta do Conselho Ultramarino, em janeiro de 1721, Carvalho de Aguiar escrevera ao soberano queixando-se de que, ainda que o rei tivesse estabelecido as normas de repartição das presas de guerra, "abusam muito de tal ordem os governadores do dito Estado, repartindo por si as ditas presas como lhes parece e tomando a titulo de joia quantas querem com exorbitante excesso". Por essa razão, ficam "a infantaria e índios sem parte nem quinhão nas ditas presas", o que lhes daria motivo a "maior murmuração e descontentamento". Como poucas peças eram dadas à tropa de guerra, entre índios e soldados, estes procuravam "matar ao gentio que lhes cai nas mãos" com prejuízo dos quintos reais e da Fazenda real.59

Os conflitos e as alianças dos governantes e moradores do Estado do Maranhão refletiam na organização das tropas. A composição de uma tropa para combater os índios obedecia, portanto, a interesses daqueles que eram responsáveis por organizar e enviar as expedições punitivas aos sertões, e dos moradores do Estado do Maranhão. Assim, as escolhas dos participantes das tropas pareciam constituir tentativas de ampliar e concretizar alianças e influências políticas.

\footnotetext{
57 Ibidem.

58 Ibidem.

59 S. e q. escreve o mestre de campo da conquista do Maranhaõ e Piauhi Bernardo de Carvalho de Aguiar. 11/12/1721. AHU, códice 274, ff. 283v-284.
} 


\section{"A paz do dito gentio". João da Maia da Gama}

Ao que tudo indica, ao assumir seu governo, João da Maia da Gama imprime uma mudança de rota na política com relação aos índios dos sertões do açúcar e do gado que se estendiam a leste do território do Estado do Maranhão e Pará. De fato, o governo do sucessor de Bernardo Pereira de Berredo foi caracterizado pela consolidação de uma relativa paz (e por uma concreta aproximação com os padres jesuítas), que se manteve com o seu sucessor, Alexandre de Sousa Freire (1728-1732). Durante o governo de João da Maia da Gama, os índios Caicai, Aruá, Barbados e Guanaré foram "pacificados" e os Tremembé aceitaram viver com os jesuítas no Piauí. Como defende Márcia Eliane Mello, embora em 1720 ainda possam ser observados conflitos com os grupos indígenas, "crescia um grande interesse por parte da administração do Estado em promover a paz". ${ }^{60}$

Isso não significa que Maia da Gama tenha totalmente abdicado do conflito armado. ${ }^{61}$ Em carta ao rei, o próprio governador refere-se a uma tropa que mandara a "castigar os Guanaré" pelas mortes que tinham causado não aos portugueses, mas, sim, aos Caicai, estes "postos na real vassalagem e obediência de V. M.". Mas a mesma carta informava das pazes que tinham pedido os próprios Guanaré (além dos Aruá) que explicavam, segundo o governador, que as mortes que tinham feito nos Caicai "foi por serem seus inimigos, e por lhe terem morto seus parentes". O governador convocou a Junta das Missões, onde expôs o caso, inclusive o problema das "queixas de desconfianças que podiam ter os nossos Caicai, de lhes não darmos satisfação com o castigo dos seus inimigos". Segundo o relato de Maia da Gama, pesadas todas as circunstâncias, entretanto, resolveu-se "aceitar-se e conceder-se pazes aos principais das ditas duas nações mais culpados". Assim, o tom da carta que o governador João da Maia da Gama escrevia ao rei, em julho de 1726 (carta que vinha acompanhada dos traslados dos termos de paz firmados com os índios), era definitivamente outro, já que insistia que as consequências das pazes

são as maiores que se podem considerar, descobrindo-se fertilíssimos campos de que dão notícia, e povoando-se com grande utilidade dos dízimos de V. M., e abrindose caminho muito mais cômodo e breve para se conduzirem gados para as minas e

\footnotetext{
${ }^{60}$ MELLO, Marcia Eliane Alves de Souza e, op. cit., p. 311.

${ }^{61}$ Ver também: MEIRELES, Mário M., op. cit., p. 146; LIMA, Carlos de, op. cit., p. 430.
} 
abrindo-se a comunicação e caminho para o rio dos Tocantins, que deságua no Pará, descobrindo-se as minas e riquezas daquele rio. ${ }^{62}$

O diário escrito por Maia da Gama sobre sua jornada de retorno a Portugal, percorrendo os sertões do Maranhão até a Paraíba, embora com um tom laudatório de sua pessoa, revela indícios de uma relação distinta com as populações indígenas dos sertões orientais do Estado do Maranhão e Pará. Saindo de São Luís em setembro de 1728, a descrição que faz dos sertões é a de uma terra pacificada onde floresciam engenhos e currais. A importância que atribui a sua ação não é nada pequena nessa enorme tarefa de pacificar os sertões.

Todos estes rios se achavam assim destruídos e despovoados até que eu, no ano de 1723, reduzi à paz os Caicai e ao depois com eles e com as diligências de paz, e que ultimamente com guerra destruí e reduzi à paz todas as ditas nações, e entreguei o governo com todos postos em paz e quietação, tendo-se passado dois anos sem que houvesse o mínimo prejuízo do dito gentio e deixei o dito rio Itapecuru navegado para algumas 70 léguas, quando cheio, e povoado até suas cabeceiras e até as margens do rio Parnaíba. ${ }^{63}$

Mas, afinal, o que teria motivado essa mudança significativa? Ao que tudo indica, a escassez de guerras durante o governo de João da Maia da Gama está relacionada a suas articulações com outros grupos da sociedade colonial, como os padres da Companhia de Jesus. João da Maia da Gama foi ao Estado do Maranhão acompanhado do desembargador Francisco da Gama Pinto, que verificaria os abusos praticados nas expedições de obtenção de mão-de-obra indígena. Para Fabiano Vilaça dos Santos, a sindicância sobre as expedições de apresamento ao sertão foi "recebida com antipatia pelos colonos que suspeitaram da articulação dos jesuítas com o novo governador para retomar a primazia na condução dos descimentos dos índios". ${ }^{4}$ Se os governos de Cristóvão da Costa Freire e Bernardo Pereira de Berredo foram períodos de favorecimento de diversos moradores no apresamento de índios, a chegada de João da Maia da Gama e do sindicante desembargador Francis-

\footnotetext{
${ }_{62}$ Carta de João da Maia da Gama. São Luís, 9/07/1726. AHU, Maranhão, documento 1525. Ver também: MELLO, Marcia Eliane Alves de Souza e, op. cit., p. 312.

${ }^{63}$ Diário da viagem de regresso para o reino de João da Maia da Gama e de inspeção das barras dos rios do Maranhão e das capitanias do norte, em 1728. In: MARTINS, Francisco de Assis Oliveira. Um herói esquecido (João da Maia da Gama). Lisboa: Agência Geral das Colónias, 1944, vol. II, p. 8.

${ }^{64}$ SANTOS, Fabiano Vilaça dos. A reação dos "cidadãos" do Estado do Maranhão aos "maus procedimentos" do governador João da Maia da Gama. REUNIÃO DA SOCIEDADE BRASILEIRA DE PESQUISA HISTÓRICA, XXIV, 2004, Curitiba. Anais. Curitiba: SBPH, 2004, p. 150.
} 
co da Gama Pinto pode ter representado uma retomada dos privilégios dos jesuítas e dos seus aliados, como lembrou Joel Dias. ${ }^{65}$

Esta proximidade do governador com os jesuítas certamente contribuiu para a maneira como João da Maia da Gama conduziu a governança do Estado do Maranhão. É provável que esta articulação tenha favorecido a aliança com os Caicai, Aruá, Barbados e Guanaré. Por um lado, Maia da Gama pode ter apoiado os jesuítas a "pacificarem" estes índios bravos. Por outro, talvez os próprios índios tenham percebido que aquele contexto era benéfico para propor aliança aos portugueses para que tivessem seus interesses assegurados.

Foi também no governo de Maia da Gama que os índios Tremembé aceitaram se aldear. Segundo relato do próprio governador, estes índios foram até ele, como costumavam fazer, "e que depois de praticados lhe disseram se queriam aldear e batizar seus filhos e lhe pediram o padre João Tavares" da Companhia de Jesus. Por essa razão, João da Maia da Gama teria mandado dar aos índios Tremembé ferramentas, anzóis e algum pano da Fazenda Real. ${ }^{66}$ Assim, parece que no governo de João da Maia da Gama houve empenho em se aproximar dos índios. Durante seu governo, não houve sucessivas guerras, como na administração de Cristóvão da Costa Freire e de Bernardo Pereira de Berredo, o que reforça a compreensão de que as guerras eram também movidas e explicadas pelas relações que os governadores construíam com as redes locais de exercício do poder.

A grande questão aqui, e cremos que não há elementos suficientes para poder respondê-la com satisfação, é a de saber qual o grau de atrelamento dessa política de relativa paz aos ditames da Coroa. Mais ainda, há que se lembrar que a conjuntura pode ter sido também fruto da ação dos próprios índios que, inclusive, podem ter percebido o momento mais favorável a eles com a chegada de Maia da Gama. Talvez, a tão propalada paz, que o próprio Maia da Gama fazia questão de frisar, só tivesse sido mesmo possível graças aos conflitos dos anos anteriores ao seu mandato, e também à própria vontade das nações indígenas. De qualquer modo, a distinção entre índios hostis e aliados, apontada pela bibliografia como uma perspectiva central para en-

\footnotetext{
${ }_{65}$ DIAS, Joel Santos, op. cit., p. 123.

${ }^{66}$ CCU, 9/12/1722. AHU, Maranhão, documento 1350. Ver: MELO, Vanice Siqueira de. Os “senhores absolutos de toda a costa" foram aldeados: o estabelecimento da aldeia dos Tremembé e o conflito com os curraleiros (séculos XVII-XVIII). ENCONTRO INTERNACIONAL DE HISTÓRIA COLONIAL, 3º, 2010, Recife. Anais. Recife: UFPE, 2011, p. 759-65. Sobre os Tremembé, ver também: BORGES, Jóina Freitas. Os senhores das dunas e os adventícios d'além-mar: primeiros contatos, tentativas de colonização e autonomia Tremembé na costa leste-oeste (séculos XVI e XVII). Tese de doutorado, História, UFF, 2010.
} 
tender a política indigenista portuguesa, ${ }^{67}$ parece ter sido mais maleável. A paz oferecida aos Guanaré e aos demais grupos marcadamente hostis parece ser um elemento nesse sentido.

Entretanto, a mudança de governo parece ter alterado as relações. A chegada de Alexandre de Sousa Freire foi marcada pela retomada de um discurso belicoso, expresso de maneira clara numa resposta do governador a uma provisão do rei que condenara a autorização que Sousa Freire tinha dado para uma guerra contra várias nações. Segundo Alexandre de Sousa Freire, "todos os gentios que infestam aqueles campos são gentios de corso que nunca se aldearam, nem os fará aldear ninguém”. Logo adiante, emenda que na Câmara de São Luís havia ordem do governador Cristóvão da Costa Freire para se guerrear o gentio do corso, "e como os que infestam as capitanias do Piauí e suas anexas são todos desta condição pela maior parte, com ela se salva todo o reparo". Enfim, escrevia que resolvera ordenar a todos os "capitães-mores daqueles sertões", que cada um "no seu distrito, fizesse a guerra". ${ }^{68}$

Acerbo inimigo dos padres jesuítas e de outras ordens religiosas, Sousa Freire foi também acusado de inúmeras irregularidades numa tropa que teria mandado desta vez à região ocidental do Estado, no sertão do rio Negro. ${ }^{69}$ Uma das razões que teriam ensejado tantas denúncias era o interesse em conseguir peças escravas por meio das guerras, recebendo as "joias" que lhe cabiam como autoridade. Ou seja, mais um governador era acusado de se favorecer ilicitamente com o envio de tropas de guerras. Não sem razão, numa

\footnotetext{
${ }^{67}$ Ver principalmente: PERRONE-MOISÉS, Beatriz. Índios livres e índios escravos. Os princípios da legislação indigenista colonial (séculos XVI a XVIII). In: CUNHA, Manuela Carneiro da (org.). História dos índios no Brasil. São Paulo: Companhia das Letras, 1992, p. 115-32.

${ }^{68}$ A resposta está incompleta e pela referência que faz dela o governador José de Serra, sabe-se que é de 11 de setembro de 1732. Está anexa a carta de José de Serra. Belém, 21 de setembro de 1732. AHU, Pará, documento 1284.

${ }^{69}$ Aliado do governador Sousa Freire era Paulo da Silva Nunes, o mais famoso detrator dos religiosos da Companhia de Jesus no Estado do Maranhão. A esse respeito, ver: SANTOS, Fabiano Vilaça dos. Pedras do ofício: Alexandre de Sousa Freire e os jesuítas no Estado do Maranhão (1728-1732). REUNIÃO DA SOCIEDADE BRASILEIRA DE PESQUISA HISTÓRICA, XXV, Rio de Janeiro, 2005. Anais. Rio de Janeiro: SBPH, 2005, p. 275-82; DIAS, Joel Santos, op. cit., p. 11339; CARVALHO JÚNIOR, Roberto Zahluth de. Espíritos inquietos e orgulhosos. Os frades capuchos na Amazônia joanina (1706-1751). Dissertação de mestrado, História, UFPA, 2009, p. 102-104; MELLO, Marcia Eliane Alves de Souza e, op. cit., p. 312-13. Ver também: REIS, Arthur Cezar Ferreira. Prestação de contas de um governante colonial do antigo Estado do Maranhão e Grão-Pará. Revista do Instituto Histórico e Geográfico Brasileiro. Rio de Janeiro: IHGB, n. 345, 1984, p. 85-99.
} 
REVISTA DE HISTÓRIA

SÃO PAULO, N 168 , p. 167-200,

JANEIRO / JUNHO 2013
Rafael Chambouleyron e Vanice Siqueira de Melo Governadores e índios, guerras e terras entre o Maranhão e o Piauí (primeira metade do século XVIII)

consulta do Conselho Ultramarino em 1730, o procurador da Coroa declarava que os governadores do Estado do Maranhão, "pelo interesse que lhes resulta nas suas joias, buscam motivo de fazerem guerra aos índios seja ou não justa" e não observam o disposto nas leis. Afirmava, igualmente, que os "prelados que assistem na Junta das Missões por seu respeito não votam com liberdade". ${ }^{70}$ A discussão acerca das "joias" prolongou-se pelos anos. A matéria sobre a jurisdição da guerra só foi resolvida quatro anos depois, quando o Estado do Maranhão e Pará já era governado por José Serra (1732-1736).71

Mas, afinal de contas, teriam sido finalmente desinfestados e pacificados os sertões do Maranhão e Piauí? A considerável expansão do gado a partir de meados dos anos 1720 parece dar conta dessa possibilidade.

\section{A guerra, a paz e a expansão do gado}

À semelhança dos sertões do gado em Pernambuco, Bahia, Paraíba, Rio Grande do Norte e Ceará, não há dúvida sobre o papel fundamental das guerras levadas a cabo na pacificação, eliminação, domesticação e reconfiguração dos índios que permitiu a expansão dos engenhos e currais de gado no lado oriental do Estado do Maranhão e Pará. ${ }^{72}$

\footnotetext{
${ }^{70}$ Sobre a guerra q. o Gov. ${ }^{\text {or }}$ do Maranhão Alexdr.e de Sousa Fr. ${ }^{\text {e }}$ mandou fazer aos Indios do Rio Negro. 21/03/1730. AHU, códice 209, ff. 28-30.

${ }^{71}$ Para o mesmo, 3/04/1734. AHU, códice 270, f. 209v. Ver: MELLO, Marcia Eliane Alves de Souza e, op. cit., p. 314.

${ }^{72}$ A respeito desses outros "sertões", ver: SILVA, Francisco Carlos Teixeira da. Pecuária, agricultura de alimentos e recursos naturais no Brasil-colônia. In: SZMRECSÁNYI, Tamás (org.). História econômica do período colonial. $2^{a}$ edição revista. São Paulo: Hucitec/ABPHE/EdUSP/Ioesp, 2002, p. 123-35; PUNTONI, Pedro, op. cit., p. 89-289; PINHEIRO, Francisco José, op. cit., p. 27-37; ALBUQUERQUE, Manuel Coelho. Seara indígena. Deslocamentos e dimensões identitárias. Dissertação de mestrado, História, UFC, 2002, p. 68-90; NEVES, Erivaldo Fagundes. Posseiros, rendeiros e proprietários: estrutura fundiária e dinâmica agromercantil no alto sertão da Bahia (1750-1850). Tese de doutorado, História, UFPE, 2003, p. 146-62; VIEIRA JR., Antonio Otaviano. Entre paredes e bacamartes: história da família no sertão (1780-1850). Fortaleza/São Paulo: Demócrito Rocha/Hucitec, 2004, p. 29-37; JESUS, Mirian Silva de. Abrindo espaços: os "paulistas" na formação da capitania do Rio Grande. Dissertação de mestrado, História, UFRN, 2007, p. 61-71 e 97-105; SILVA, Rafael Ricarte da. Formação da elite colonial dos sertões de Mombaça: terra, família e poder (século XVIII). Dissertação de mestrado, História, UFC, 2010, p. 75-93; MAIA, Lígio José de Oliveira. Serras de Ibiapaba. De aldeia a vila de índios: vassalagem e identidade no Ceará colonial - século XVIII. Tese de doutorado, História, UFF, 2010, p. 83-92; SILVA, Kalina Vanderlei. Nas solidões vastas e assustadoras: a conquista do sertão de Pernambuco pelas vilas açucareiras nos séculos XVII e XVIII. Recife: Cepe, 2010, p. 195-213; ALVEAL,
} 
Assim, a relação entre os governadores e as guerras se conectava igualmente a outro aspecto importante da experiência colonial da América portuguesa, a distribuição de terras. Em todo o Estado do Maranhão e Pará, pelo menos até meados do século XVIII, não houve distribuição de terras em sesmaria senão por parte dos governadores (excetuando-se alguns poucos casos nas capitanias de donatários). Assim, a articulação das guerras contra os índios e da concessão de sesmarias na porção oriental do Estado revela a imbricada relação que, por meio do poder dos governadores, assumiam essas múltiplas formas de ocupação do espaço.

Como era de se esperar, a guerra significava uma forma de acesso a terra. Isso por duas razões. Ela permitia que indivíduos que tivessem participado das pelejas legitimassem os seus pedidos. Isso valia não só para os soldados das expedições comandadas ou ordenadas pelos governadores, mas também para aqueles que a sua custa e fazenda empreendiam ações contra os índios. Por outro lado, os embates "desinfestavam" os sertões, como se dizia à época.

Alguns dos participantes das várias expedições para combater os índios no sertão ao longo da primeira metade do século XVIII conseguiram sesmarias e se instalaram, justamente, nos sertões que haviam ajudado e ajudavam a devassar. Era o caso, por exemplo, de Damaso Pinheiro de Carvalho, "um dos primeiros povoadores da capitania do Piauí" (1715, riacho das Cabras) ${ }^{73}$ do nosso já conhecido Francisco Cavalcante de Albuquerque (1719, rio Mearim) ${ }^{74}$ de Francisco de Almeida, "capitão da conquista atual" (1727, rio Mearim) ${ }^{75}$ de Manuel da Silva Pereira (1726, próximo ao rio Parnaíba); ${ }^{76}$ de Antônio Gomes Leite (1728, próximo ao rio Gurgueia); ${ }^{77}$ e de João Nogueira de Sousa (1729, instalado no Itapecuru). ${ }^{78}$

Carmen e SILVA, Thyego Franklin. Na ribeira da discórdia: povoamento, políticas de defesa e conflitos na capitania do Rio Grande (1680-1710). In: POSSAMAI, Paulo (org.). Conquistar e defender: Portugal, Países Baixos e Brasil. Estudos de história militar na Idade Moderna. São Leopoldo: Oikos, 2012, p. 235-49.

${ }^{73}$ Damaso Pinheiro de Carvalho, em 12/01/1715; confirmação em 14/09/1722. ANTT, Chancelaria de Dom João V, livro 60, ff. 226v-227v.

${ }^{74}$ Francisco Cavalcante de Albuquerque, em 11/12/1719; confirmação em 27/04/1724. ANTT, Chancelaria de Dom João V, livro 61, ff. 101-102.

${ }^{75}$ Francisco de Almeida, em 5/05/1727; retificada em 5/01/1735; confirmação em 4/02/1737. Apep, Sesmarias, livro 3, ff. 68-68v e livro 7, ff. 70-70v. ANTT, Chancelaria de Dom João V, livro 129, ff. 71-72.

${ }^{76}$ Manuel da Silva Pereira, em 18/01/1726; confirmação em 22/03/1728. ANTT, Chancelaria de Dom João V, livro 75, ff. 59-60.

77 Antônio Gomes Leite, em 12/07/1728. Apep, Sesmarias, livro 5, ff. 11-11v.

${ }^{78}$ João Nogueira de Sousa, em 21/07/1729. Apep, Sesmarias, livro 5, ff. 77-78. 
Por outro lado, em vários pedidos de terras reproduzidos nas concessões, há referências à ação dos "tapuias" dos sertões e ao papel dos próprios "suplicantes" nos conflitos contra os índios. Manuel Pires Ribeiro, sargento-mor do Parnaíba, por exemplo, alegava ter povoado com gado o sítio Santo Antônio da Boa Vista e Almas, no rio Longá, onde tinha "todas as fábricas necessárias de escravos, criados, cavalos, ferramentas, armas e munições", com as quais "o está defendendo da invasão do gentio bárbaro que costuma assaltar as capitanias do Piauí". A sesmaria foi concedida por Pereira de Berredo em 1720.79

Dois anos depois, em 1722, a família Álvares de Sousa se apossava de consideráveis extensões de terra no rio Paraim, a começar pelo capitão-mor Manuel Álvares de Sousa, que solicitava três léguas e justificava seu pedido alegando

muito dispêndio da sua fazenda e risco de vida com homens, e gentios forros assalariados com muitas mortandades de gentio bravo com muitas tropas que lhe fez, e está fazendo como é notório, tem descoberto e desinfestado muitas terras e sertões daquela dita capitania. ${ }^{80}$

Os filhos do capitão-mor, Maria, Tomé e Manuel, também moradores no Parnaguá, requeriam suas três léguas cada um baseados nos notórios serviços de seu pai. ${ }^{81}$ Entretanto, apesar de tanta "desinfestação" dos sertões, a sorte não sorria para os Álvares de Sousa. Pareceres do procurador da Fazenda nos quatro requerimentos recomendavam que se negasse a confirmação (como, de fato, não há registro delas nas chancelarias ou Registro Geral de Mercês). O argumento era o tamanho das concessões. Embora os governadores costumassem passar pelo menos três léguas para criação de gado, de regra confirmadas pelos reis, certamente deve ter saltado aos olhos do Conselho Ultramarino e dos procuradores a acumulação de tantas datas numa mesma família. Já o sobrinho de Manuel Álvares de Sousa teve mais sorte; anos depois, em 1729, informava ter comprado terras deste e de outro tio seu, "a qual tinha povoado a sua custa e descoberto e tirado do poder do

\footnotetext{
${ }^{79}$ Manuel Pires Ribeiro, em 27/07/1720; confirmação em 30/04/1724. ANTT, Registro Geral de Mercês, Dom João V, livro 15, ff. 431-431v.

${ }^{80}$ Requerimento de Manuel Álvares de Sousa solicitando confirmação de sesmaria concedida em 28/02/1722. AHU, Piauí, documento 80.

${ }^{81}$ Requerimento de Maria Álvares de Sousa solicitando confirmação de sesmaria concedida em 26/02/1722. AHU, Maranhão, documento 1870; Requerimento de Tomé Álvares de Sousa solicitando confirmação de sesmaria concedida em 28/02/1722. AHU, Piauí, documento 62; Requerimento de Manuel Álvares de Sousa (filho) solicitando confirmação de sesmaria concedida em 1/03/1722. AHU, Piauí, documento 78.
} 
gentio bárbaro, com perda de sua fazenda". Concedida a terra, foi finalmente confirmada em 1732. ${ }^{82} \mathrm{O}$ importante, de qualquer modo, no caso dos Álvares de Sousa, é o fato de que o governador concedera as terras e que a guerra contra o gentio era o principal argumento dos pedidos.

Anos antes, no governo de João da Maia da Gama, Veríssimo Manuel Robalo Freire justificava seu pedido por ter desinfestado de "gentio bárbaro" um sítio na ribeira do Gurgueia. Depois de visto o parecer do procurador da Fazenda do Piauí e um sumário de testemunhas, o próprio governador reconhecia na concessão que Robalo Freire povoara a região "com gados vacuns e cavalares, escravos e homens brancos que o beneficiam, e casa de vivenda, o qual sítio estava despovoado por causa do morcego e gentio". ${ }^{33} \mathrm{Em}$ 1729, Alexandre de Sousa Freire concedia uma data de terra a João Carvalho Ramos que alegava ter povoado um sítio no Gurgueia, "desinfestando do gentio bárbaro, com grande risco de sua vida e seus escravos"; acrescentava Carvalho Ramos que combatera os índios, inclusive, não só na "desinfestação e povoação do dito sítio", mas também nas "mais ocasiões de bandeiras que se deram ao dito gentio". ${ }^{84}$ Havia aqui um misto de guerra "oficial" e "privada" que indica o imbricamento de uma ação que partia dos governadores e outra que partia dos "particulares", embora se entrecruzando quando os interesses fossem os mesmos.

As referências aos conflitos, entretanto, eram mais complexas, pois não necessariamente decorriam de uma participação individual e direta dos requerentes (ou seus ascendentes) na guerra ou no combate aos "tapuias". Na década de 1710, por exemplo, durante o beligerante governo de Cristóvão da Costa Freire, em quatro sesmarias no rio Itapecuru, todas concedidas em julho de 1713, João Rebelo Bandeira, ${ }^{85}$ Felipe Borges, ${ }^{86}$ Manuel Borges ${ }^{87} \mathrm{e}$ Manuel Nunes Coelho da Costa, ${ }^{88}$ moradores no Piauí, reproduziam a mes-

\footnotetext{
${ }^{82}$ Paulo Carvalho da Cunha, em 24/05/1729; confirmação em 9/06/1732. ANTT, Chancelaria de Dom João V, livro 82, ff. 53v-54v.

${ }^{85}$ Veríssimo Manuel Robalo Freire, em 15/06/1727. Apep, Sesmarias, livro 3, ff. 132-132v.

${ }^{84}$ João Carvalho Ramos, em 24/05/1729. Apep, Sesmarias, livro 4, ff. 170-171.

${ }^{85}$ João Rebelo Bandeira, em 25/07/1713; confirmação em 17/02/1715. ANTT, Chancelaria de Dom João V, livro 43, ff. 119-120v.

${ }^{86}$ Felipe Borges, em 25/07/1713; confirmação em 10/03/1716. ANTT, Chancelaria de Dom João V, livro 45, ff. 91-92.

${ }^{87}$ Manuel Borges, em 25/07/1713; confirmação em 10/03/1716. ANTT, Chancelaria de Dom João V, livro 45, ff. 89-90.

${ }^{88}$ Manuel Coelho da Costa, em 25/07/1713; confirmação em 10/03/1716. ANTT, Chancelaria de Dom João V, livro 45, ff. 90-91.
} 
ma expressão, alegando que a concessão era "muito conveniente não só às rendas reais desta capitania para a tropa de guerra que anda no sertão, mas também por ser aquela parte o couto de maior poder do gentio do corso, que infesta estas capitanias".

Em várias concessões, a referência às terras infestadas pelos gentios do corso legitimava o pedido dos requerentes, pois a ação de "desinfestação" e povoamento valorizava o que claramente aparecia como ermo e selvagem, uma verdadeira ação "civilizadora" (apesar de este termo não aparecer na documentação). Aqui, terra devoluta e presença de índios hostis apareciam como indissociáveis, como na concessão dada a Felipe Santiago, Luís Pinheiro Lobo e Manuel Vieira Botado (1713) que frisava que "nas ribeiras do rio do Mearim se achavam algumas [terras] devolutas e infestadas do gentio bárbaro de corso". ${ }^{99}$ Em 1719, há quatro concessões no rio Iguará, com requerimentos (transcritos nas datas) muito semelhantes, o que indica uma ação orquestrada entre requerentes e o governador - no caso Bernardo Pereira de Berredo - em que se repetia uma fórmula que enfatizava o fato de as terras serem ao mesmo tempo devolutas e "só" serem ocupadas pelo "gentio bárbaro". ${ }^{90}$ Era o caso das sesmarias dadas a Pedro Oliveira Jardim, ${ }^{91}$ Antônio da Silva Moura, ${ }^{92}$ Simão da Silva ${ }^{93}$ e Miguel da Silva. ${ }^{94}$

Assim, devoluto não só não significava mais a terra que voltava à Coroa, mas assumia o caráter de vazio, de intocado, condição agravada pela existência de gentio bárbaro. Em 1727, a sesmaria concedida a João Gomes no

\footnotetext{
${ }^{89}$ Felipe Santiago, Luís Pinheiro Lobo e Manuel Vieira Botado, em 20/07/1713; confirmação em 6/03/1715. ANTT, Chancelaria de Dom João V, livro 48, ff. 334-335v.

${ }^{90}$ Esta ideia de vazio associada aos índios não pode ser generalizada para a América portuguesa. Afinal, ainda no século XVIII, principalmente na segunda metade, a presença dos grupos indígenas se tornava fundamental para garantir a própria soberania portuguesa sobre o território. Ver: MALDI, Denise. De confederados a bárbaros: a representação da territorialidade e da fronteira indígenas nos séculos XVIII e XIX. Revista de Antropologia. São Paulo: FFLCH/USP, vol. 40, n 2, 1997, p. 183-221; DOMINGUES, Ângela. Quando os índios eram vassalos. Colonização e relações de poder no norte do Brasil na segunda metade do século XVIII. Lisboa: CNCDP, 2000, p. 199-246; COELHO, Mauro Cezar. Do sertão para o mar. Um estudo sobre a experiência portuguesa na América, a partir da colônia: o caso do Diretório dos Índios (1751-1798). Tese de doutorado, História, USP, 2005, p. 105-14.

${ }^{91}$ Pedro Oliveira Jardim, em 22/05/1719; confirmação em 11/05/1724. Apep, Sesmarias, livro 2, ff. $162-163 \mathrm{v}$.

${ }^{92}$ Requerimento de Antônio da Silva Moura solicitando confirmação de sesmaria concedida em 21/08/1719. AHU, Maranhão, documento 1349.

${ }^{93}$ Requerimento de Simão da Silva solicitando confirmação de sesmaria concedida em 21/08/1719. AHU, Piauí, documento 14.

${ }^{94}$ Requerimento de Miguel da Silva solicitando confirmação de sesmaria concedida em 22/08/1719. AHU, Piauí, documento 13.
} 
sertão do Gurgueia expressa essa condição, ao se referir a "terras desertadas do gentio do corso". ${ }^{95}$ Poucos anos depois, a concessão dada a Francisco Xavier Chaves deixava claro essa múltipla condição "se acham devolutas por nunca serem povoadas, nem pedidas por outra alguma pessoa por serem infestadas do gentio do corso".96 Para os portugueses, definitivamente, os índios do corso ajudavam a construir uma paisagem selvagem e "vazia" que cabia aos moradores transformar. ${ }^{97}$

Assim, o espaço ocupado pelas sesmarias e a forma como ele é referido são marcados pelos conflitos contra os índios e a territorialidade que a guerra ensejava, inclusive na própria toponímia. Em duas datas de terras, os pedidos, reproduzidos nas concessões, faziam referência ao mestre de campo Antônio da Cunha Souto Maior. Francisco do Rego Monteiro era um deles e pedia três léguas no "rio Negro na passagem por onde passava o defunto mestre de campos Antônio da Cunha Souto Maior".98 Já Hilário Vieira de Carvalho pedia também três léguas "em uma lagoa na estrada que abriu o defunto mestre de campo Antônio da Cunha Souto Maior".99

Mas a "desinfestação" dos sertões, durante os governos de Cristóvão da Costa Freire e Bernardo Pereira de Berredo, entre 1707 e 1722, permitiu igualmente a expansão do Estado do Maranhão e Pará para o leste. Entre agosto de 1723 e maio de 1728, durante o governo de João da Maia da Gama, foram concedidas 157 sesmarias, principalmente nos rios Itapecuru, Munim, Iguará e Gurgueia (145 delas entre 1725 e 1728). ${ }^{100}$ O próprio governador, no relato da viagem que fez de volta do Maranhão, como vimos, ressalta o seu papel no processo de expansão desencadeado pelas concessões de terra. Ao longo do diário de sua jornada, faz questão de marcar as "novas fazendas" estabelecidas pelos vastos sertões orientais do Estado do Maranhão, "fazendas [que] se povoaram com outras muitas que ficam fora do caminho para uma e outra parte depois que meti de paz os Cahicahires [Caicai]". ${ }^{101}$ Pouco adiante, insiste em seu papel pacificador/povoador:

\footnotetext{
95 João Gomes, em 4/08/1727. Apep, Sesmarias, livro 3, ff. 156v-157.

${ }^{96}$ Francisco Xavier Chaves, em 14/03/1732. Apep, Sesmarias, livro 6, ff. 56-56v.

${ }_{97}$ Ver: MACHADO, Marina Monteiro. Entre fronteiras: posses e terras indígenas nos sertões (Rio de Janeiro, 1790-1824). Rio de Janeiro/Guarapuava: EdUFF/Unicentro, 2012, p. 42.

${ }^{98}$ Francisco do Rego Monteiro, em 6/05/1728. Apep, Sesmarias, livro 4, ff. 49-49v.

${ }^{99}$ Hilário Vieira de Carvalho, em 6/05/1728. Apep, Sesmarias, livro 4, ff. 49v-50v.

${ }^{100}$ Ver: Apep, Sesmarias, livros 1 a 4.

${ }^{101}$ Diário da viagem de regresso para o reino de João da Maia da Gama e de inspeção das barras dos rios do Maranhão e das capitanias do norte, em 1728. In: MARTINS, Francisco de Assis Oliveira, op. cit., p. 12.
} 
e todas estas terras era domicílio do gentio que meti de paz e estava assaltando os comboios e matando muita gente sem embargo de irem armados e com tropa, o que fazia intratável a comunicação do Piauí com o Maranhão e com as fazendas de todas as margens do Parnaíba. ${ }^{102}$

Qualquer que seja o papel que o próprio governador quer assumir no seu relato (recheado de seus feitos de governo, por sinal), não resta dúvida de que, como dissemos anteriormente, o governo de Maia da Gama foi de relativa paz, fruto de uma política beneficiada pela aproximação do governador com os padres jesuítas que tantos atritos causou com os moradores. E, principalmente, fruto das guerras anteriores. Por outro lado, coincidência ou não, pouco mais de 90\% das sesmarias concedidas se concentra no período que sucede a uma epidemia de bexigas. ${ }^{103}$ Entretanto, a varíola dos anos 1724-1725 castigou muito mais a capitania do Pará do que as do Maranhão e Piauí, o que não nos permite chegar a nenhuma relação conclusiva entre a distribuição de terras e as consequências do surto de varíola.

Certamente, a conjuntura favorável, criada nas primeiras décadas do século XVIII, por meio da guerra e também da paz, permitiu a continuação de uma política de distribuição de terras no governo do sucessor de Maia da Gama, Alexandre de Sousa Freire, que concedeu 130 sesmarias nos sertões orientais do Estado, de junho de 1728 a março de 1732. ${ }^{104}$ Aliás, com Sousa Freire a expansão se concretizava cada vez mais a leste. De fato, além dos rios Itapecuru, Munim, Mearim, Iguará, Gurgueia, Parnaíba, onde assentava ou confirmava criadores de gado, chegou a conceder dez datas a moradores que se estabeleciam ao pé da serra de Ibiapaba, gerando conflitos com o capitão-mor do Ceará, expressos em algumas das próprias concessões. ${ }^{105}$

\footnotetext{
${ }^{102}$ Ibidem, p. 13.

${ }^{103}$ Ver: SOUSA, Claudia Rocha de. O "Iastimoso castigo e fatal estrago" das epidemias no Estado do Maranhão e Grão-Pará na primeira metade do século XVIII. Monografia de graduação, História, Faculdade de História, UFPA, 2011, p. 35-41.

${ }^{104}$ Ver: Apep, Sesmarias, livros 4 a 6.

${ }^{105}$ Antônio Gomes Linhares, em 22/06/1729. Apep, Sesmarias, livro 4, ff. 185-185v; Maurício Gomes, em 13/07/1729. Apep, Sesmarias, livro 4, ff. 176-176v; Domingos Ferreira Chaves, em 22/07/1729. Apep, Sesmarias, livro 4, ff. 183v-184; Bernardo Vieira da Silva, em 22/07/1729. Apep, Sesmarias, livro 4, ff. 184-185; Manuel de Medeiros Garcês, em 1/08/1729. Apep, Sesmarias, livro 5, ff. 82-82v; Manuel Gomes Pereira, em 1/08/1729. Apep, Sesmarias, livro 5, ff. 82v-83v; João Batista, em 12/04/1730. Apep, Sesmarias, livro 5, ff. 125v-126; Lourenço de Andrade Passos, em 12/04/1730. Apep, Sesmarias, livro 5, ff. 126-126v; Manuel Batista, em 29/04/1730. Apep, Sesmarias, livro 5, ff. 129v-130; Antônio de Medeiros, em 22/07/1729. Apep, Sesmarias, livro 5, ff. 78-79. Também foi concedida uma sesmaria no Canindé: João Batista Pinto, em
} 
A origem dos sesmeiros - a partir dos dados que eles próprios fornecem em sua petição parcialmente reproduzida nas concessões - indica que a expansão na porção oriental do Estado, em grande medida, se fazia num território em parte ocupado. Das terras concedidas por João da Maia da Gama, 78 possuem indicação da moradia do sesmeiro. Desses, 31 se apresentam como moradores de São Luís. No caso das terras dadas por Alexandre de Sousa Freire, das 73 que possuem indicação da origem dos sesmeiros, somente em 18 delas aparece a cidade de São Luís. Com todo o cuidado que temos que ter com esses dados, eles indicam, por um lado, que os governadores do Estado do Maranhão e Pará tiveram um papel importante na consolidação de um povoamento que inicialmente se estabelecera em finais do século XVII, vindo do Estado do Brasil, no caso específico do Piauí, ${ }^{106}$ e do próprio Maranhão, no caso desta capitania. ${ }^{107}$ Mas, por outro lado, notadamente com João da Maia da Gama, há um movimento populacional que parece se originar em São Luís, lugar em que a influência dos governadores e das redes que construíam era significativa.

\section{Considerações finais}

Do fim do século XVII às primeiras décadas do século XVIII, as capitanias do Maranhão e Piauí assistiram a um incremento dos conflitos com os índios e concomitantemente à expansão do gado, processo legitimado pelas inúmeras concessões de sesmarias por parte dos governadores do Estado. A ocupação desses sertões, que data de princípios do século XVII, fez-se fundamentalmente em duas frentes: uma partindo de São Luís em direção ao sudeste (a mais antiga) e a outra partindo da Bahia em direção ao oeste. Ambas só se consolidam realmente em finais do século XVII. Desde meados do século XVII e à época da incorporação da capitania do Piauí ao Estado do Maranhão e Pará, no início do século XVIII, se avigora outra força política que são os go-

30/06/1728. Apep, Sesmarias, livro 4, f. 120. João da Maia da Gama também concedeu uma sesmaria no que hoje seria território cearense, riacho Pacoti: Antônio de Andrade do Couto, em 9/05/1728. Apep, Sesmarias, livro 4, ff. 56-56v. A notícia dessas sesmarias foi divulgada há quase cem anos no Ceará: MUNIZ, João de Palma. Sesmarias cearenses. Revista Trimensal do Instituto do Ceará. Fortaleza: Instituto do Ceará, tomo XXXII, 1918, p. 3-6.

${ }^{106}$ Ver a listagem de fazendas referidas pelo padre Miguel Carvalho em 1697. Dezcripção do certão do Peauhy Remetida ao Illm. ${ }^{\circ}$ e Rm. ${ }^{\circ}$ S. ${ }^{\text {or }}$ Frei Francisco de Lima Bispo de Pernam. ${ }^{\text {co }}$. 2/03/1697. In: ENNES, Ernesto, op. cit., p. 370-87.

${ }^{107}$ Ver: CABRAL, Maria do Socorro Coelho, op. cit., p. 59-73. 
vernadores do Estado. As guerras e a distribuição de terras se tornam aí um elemento importante dos poderes que exercem as autoridades régias; daí que seus interesses pessoais (e de suas redes) apareçam por meio do seu complexo envolvimento nos empreendimentos militares e na concessão de sesmarias.

Significativamente, o período de maior distribuição de sesmarias, que ocorre durante os governos de João da Maia da Gama e Alexandre de Sousa Freire (287 sesmarias na região oriental do Estado), coincide somente em parte com o auge da distribuição de terras na região mais próxima e contígua à porção oriental do Estado do Maranhão e Pará, a capitania do Ceará, território também marcado pela economia do gado. ${ }^{108} \mathrm{O}$ incremento dos conflitos no Maranhão e Piauí, por outro lado, não necessariamente coincide com o auge das guerras no século XVIII, nos sertões do atual nordeste. ${ }^{109}$

Nesse sentido, há indícios para se pensar, no caso do Maranhão e do Piauí, na existência, paralelamente a uma política mais global da Coroa, de outras forças e interesses, como os representados pelos governadores nesse cenário de conflitos. De qualquer modo, há ainda que se compreender melhor a conexão entre o Maranhão/Piauí e o norte do Estado do Brasil, no que diz respeito à relação entre guerras e gado (evitando uma projeção automática de sentidos e dinâmicas espaciais). Mais ainda, é preciso descortinar, para além das relações políticas, as dinâmicas espaciais e populacionais que dão sentido à multidirecional ocupação dos sertões orientais do Estado do Maranhão e Pará, aprofundando a compreensão dos interesses dos diversos grupos envolvidos nesse processo, não só a Coroa, as autoridades régias, os poderes locais, os moradores, os religiosos, mas também os próprios grupos indígenas.

\section{Referências bibliográficas}

\section{Fontes impressas}

Anais da Biblioteca Nacional. Rio de Janeiro: Biblioteca Nacional, vol. 67, 1948.

ARANHA, Manuel Guedes. Papel político sobre o Estado do Maranhão. Revista do Instituto Histórico e Geográfico Brasileiro. Rio de Janeiro: IHGB, tomo 46, 1883 [c. 1682], $1^{\text {a }}$ parte, p. $1-60$.

BERREDO, Bernardo Pereira de. Annaes historicos do Estado do Maranhaõ. Lisboa: Na Officina de Francisco Luiz Ameno, 1749.

BETTENDORFF, João Felipe, SJ. Crônica da missão dos padres da Companhia de Jesus no Maranhão. Belém: Secult, 1990 [1698].

\footnotetext{
${ }^{108}$ PINHEIRO, Francisco José, op. cit., p. 31.

${ }^{109}$ PUNTONI, Pedro, op. cit., p. 283.
} 
Dezcripção do certão do Peauhy Remetida ao Illm. ${ }^{\circ}$ e Rm. ${ }^{\circ}$ S. ${ }^{\text {or }}$ Frei Francisco de Lima Bispo de Pernam. ${ }^{\text {co }} .2$ de março de 1697. In: ENNES, Ernesto. As guerras nos Palmares. São Paulo: Companhia Editora Nacional, 1938, p. 370-89.

Diário da viagem de regresso para o reino de João da Maia da Gama e de inspeção das barras dos rios do Maranhão e das capitanias do norte, em 1728. In: MARTINS, Francisco de Assis Oliveira. Um herói esquecido (João da Maia da Gama). Lisboa: Agência Geral das Colónias, vol. II, 1944.

HERIARTE, Maurício de. Descrição do Estado do Maranhão, Pará, Corupá e rio das Amazonas. In: VARNHAGEN, Francisco Adolfo de. História geral do Brasil. $8^{\mathrm{a}}$ edição. São Paulo: Melhoramentos, 1975, tomo 3, p. 170-190.

SILVEIRA, Simão Estácio da. Relaçaõ Sumaria das cousas do Maranhão. Escripta pello Capitão Symão Estacio da Sylveira. Dirigida aos pobres deste Reyno de Portugal. ABN. Rio de Janeiro: Biblioteca Nacional, vol. 94, 1974 [1624], p. 95-122.

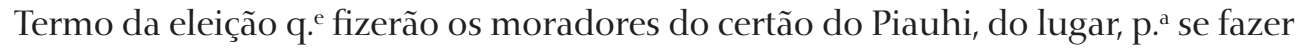
a Ig. ${ }^{\text {ja }}$ de Nossa Senhora da Victoria. 11 de fevereiro de 1697. In: ENNES, Ernesto. As guerras nos Palmares. São Paulo: Companhia Editora Nacional, 1938, p. 364-65.

Arquivo Público do Estado do Maranhão (Apem). Livro de correspondência (16961798). São Luís.

Arquivo Público do Estado do Pará (Apep). Sesmarias, livros 2 a 6. Belém.

Arquivo Histórico Ultramarino (AHU). Lisboa (Projeto Resgate). Pará, documentos 356, 519, 1284. Maranhão, documentos 463,912,977,1198, 1199, 1238, 1252, 1296, 1349, 1350, 1525, 1870. Piauí, documentos 13, 14, 62, 78, 80; códices 209, 270, 274.

Biblioteca da Ajuda. Lisboa. Códices 50-V-34 e 50-V-37.

Arquivo Nacional da Torre do Tombo (ANTT). Lisboa, Chancelaria de Dom João $\mathrm{V}$, livros 43, 45, 48, 60, 61, 75, 82, 129.

Registro Geral de Mercês, Dom João V, livro 15.

\section{Bibliografia}

ABREU, João Capistrano de. Capítulos de história colonial. Brasília: Conselho Editorial do Senado Federal, 1998.

ALBUQUERQUE, Manuel Coelho. Seara indígena. Deslocamentos e dimensões identitárias. Dissertação de mestrado, História, Programa de Pós-Graduação em História, Universidade Federal do Ceará, 2002.

ALENCASTRE, José Martins Pereira de. Memória cronológica, histórica e corográfica da província do Piauí. Revista do Instituto Histórico e Geográfico Brasileiro. Rio de Janeiro: IHGB, tomo 20, [1857], p. 5-164.

ALENCASTRO, Luiz Felipe de. O trato dos viventes. Formação do Brasil no Atlântico sul. São Paulo: Companhia das Letras, 2000.

ALVEAL, Carmen e SILVA, Thyego Franklin. Na ribeira da discórdia: povoamento, políticas de defesa e conflitos na capitania do Rio Grande (1680-1710). In: POSSAMAI, Paulo (org.). Conquistar e defender: Portugal, Países Baixos e Brasil. Estudos de história militar na Idade Moderna. São Leopoldo: Oikos, 2012, p. 235-49. 
BORGES, Jóina Freitas. Os senhores das dunas e os adventícios d'além-mar: primeiros contatos, tentativas de colonização e autonomia Tremembé na costa leste-oeste (séculos XVI e XVII). Tese de doutorado, História, Programa de Pós-Graduação em História, Universidade Federal Fluminense, 2010.

BRANDÃO, Tanya Maria Pires. A elite colonial piauiense: família e poder. Teresina: Fundação Cultural Monsenhor Chaves, 1995.

CABRAL, Maria do Socorro Coelho. Caminhos do gado: conquista e ocupação do sul do Maranhão. São Luís, Sioge, 1992.

CARDOSO, Alírio Carvalho. Maranhão na Monarquia hispânica: intercâmbios, guerra e navegação nas fronteiras das Índias de Castela (1580-1655). Tese de doutorado, História, Facultad de Geografía e Historia, Universidad de Salamanca, 2012.

CARVALHO JÚNIOR, Roberto Zahluth de. Espíritos inquietos e orgulhosos. Os frades capuchos na Amazônia joanina (1706-1751). Dissertação de mestrado, História, Programa de Pós-Graduação em História, Universidade Federal do Pará, 2009.

CHAMBOULEYRON, Rafael. Povoamento, ocupação e agricultura na Amazônia colonial (1640-1706). Belém: Açaí/PPHIST/CMA, 2010.

CHAMBOULEYRON, Rafael, BARBOSA, Benedito Costa, BOMBARDI, Fernanda Aires e SOUSA, Claudia Rocha de. "Formidável contágio". Epidemias, trabalho e recrutamento na Amazônia colonial (1660-1750). História, Ciências, Saúde Manguinhos. Rio de Janeiro: Casa Oswaldo Cruz, vol. 18, n. 4, 2011, p. 987-1004.

CHAMBOUlEYRON, Rafael e MELO, Vanice Siqueira de. Índios, engenhos e currais na fronteira oriental do Estado do Maranhão e Pará (século XVII). In: MOTTA, Márcia, SERRÃO, José Vicente e MACHADO, Marina (orgs.). Em terras lusas: conflitos e fronteiras no Império português. Guarapuava/Niterói: Unicentro/ EdUFF, 2012, p. 236-64.

COELHO, Mauro Cezar. Do sertão para o mar. Um estudo sobre a experiência portuguesa na América, a partir da colônia: o caso do Diretório dos Índios (1751-1798). Tese de doutorado, História, Programa de Pós-Graduação em História, Universidade de São Paulo, 2005.

COSTA, Francisco Augusto Pereira da. Cronologia histórica do Estado do Piauí. $2^{\text {a }}$ edição. Rio de Janeiro: Editora Artenova, [1909] 1974.

DIAS, Camila Loureiro. Civilidade, cultura e comércio: os princípios fundamentais da política indigenista na Amazônia (1614-1757). Dissertação de mestrado, História, Programa de Pós-Graduação em História, Universidade de São Paulo, 2009.

DIAS, Joel Santos. Os "verdadeiros conservadores" do Estado do Maranhão: poder local, redes de clientela e cultura política na Amazônia colonial (primeira metade do século XVIII). Dissertação de mestrado, História, Programa de Pós-Graduação em História, Universidade Federal do Pará, 2008.

DOMINGUES, Ângela. Quando os índios eram vassalos. Colonização e relações de poder no norte do Brasil na segunda metade do século XVIII. Lisboa: CNCDP, 2000.

FEIO, David Salomão Silva. As câmaras municipais: administração, elites e exercício do poder local na Amazônia colonial (1707-1722). Monografia de graduação, História, Faculdade de História, Universidade Federal do Pará, 2007.

GALINDO, Marcos. Governo das almas: A expansão colonial no país dos tapuia. 1651-1798. Tese de doutorado, História, Universiteit Leiden, 2004. 
GOULART, José Alípio. O Brasil do boi e do couro. Rio de Janeiro: Edições GDR, 1965, vol. 1.

GUZMÁN, Décio de Alencar. A colonização nas Amazônias: guerras, comércio e escravidão nos séculos XVII e XVIII. Revista Estudos Amazônicos. Belém: Universidade Federal do Pará, vol. III, nº 2, 2008, p. 103-39.

HEMMING, John. Red gold: the conquest of the Brazilian Indians. Londres: Papermac, 1995.

JESUS, Mirian Silva de. Abrindo espaços: os "paulistas" na formação da capitania do Rio Grande. Dissertação de mestrado, História, Universidade Federal do Rio Grande do Norte, 2007.

LIMA, Carlos de. História do Maranhão. $2^{\mathrm{a}}$ edição revista e ampliada. São Luís: Instituto Geia, 2006.

LIMA SOBRINHO, Barbosa. O devassamento do Piauí. São Paulo: Companhia Editora Nacional, 1946.

MACHADO, Marina Monteiro. Entre fronteiras: posses e terras indígenas nos sertões (Rio de Janeiro, 1790-1824). Rio de Janeiro/Guarapuava: EdUFF/Unicentro, 2012.

MAIA, Lígio José de Oliveira. Serras de Ibiapaba. De aldeia a vila de índios: vassalagem e identidade no Ceará colonial - século XVIII. Tese de doutorado, História, Programa de Pós-Graduação em História, Universidade Federal Fluminense, 2010.

MALDI, Denise. De confederados a bárbaros: a representação da territorialidade e da fronteira indígenas nos séculos XVIII e XIX. Revista de Antropologia. São Paulo: FFLCH/USP, vol. 40, nº 2, 1997, p. 183-221.

MARQUES, Cezar Augusto. Diccionario historico-geographico da provincia do Maranhão. Maranhão: Typ. do Frias, 1870.

MEIRELES, Mário M. História do Maranhão. São Paulo: Siciliano, 2001.

MELLO, Marcia Eliane Alves de Souza e. Fé e império: as Juntas das Missões na conquista portuguesa. Manaus: EdUFAM, 2009.

MELO, Vanice Siqueira de. Os "senhores absolutos de toda a costa" foram aldeados: o estabelecimento da aldeia dos Tremembé e o conflito com os curraleiros (séculos XVII-XVIII). ENCONTRO INTERNACIONAL DE HISTÓRIA COLONIAL, $3^{\circ}$, 2010, Recife. Anais. Recife: UFPE, 2011, p. 759-65.

MOTA, Antonia da Silva. As famílias principais: redes de poder no Maranhão colonial. São Luís: EdUFMA, 2012.

MOTT, Luiz. Piauí colonial. População, economia e sociedade. Teresina: Projeto Petrônio Portella, 1985.

MUNIZ, João de Palma. Sesmarias cearenses. Revista Trimensal do Instituto do Ceará. Fortaleza: Instituto do Ceará, tomo XXXII, 1918, p. 3-6.

NEVES, Erivaldo Fagundes. Posseiros, rendeiros e proprietários: estrutura fundiária e dinâmica agromercantil no alto sertão da Bahia (1750-1850). Tese de doutorado, História, Universidade Federal de Pernambuco, 2003.

NUNES, Odilon. Pesquisas para história do Piauí. Teresina: Imprensa Oficial, 1966, vol. I.

PERRONE-MOISÉS, Beatriz. Índios livres e índios escravos. Os princípios da legislação indigenista colonial (séculos XVI a XVIII). In: CUNHA, Manuela Carneiro da (org.). História dos índios no Brasil. São Paulo: Companhia das Letras, 1992, p. 115-32. 
PINHEIRO, Francisco José. Mundos em confronto: povos nativos e europeus na disputa pelo território. SOUSA, Simone de (org.). Uma nova história do Ceará. $2^{\mathrm{a}}$ edição. Fortaleza: Edições Demócrito Rocha, 2002, p. 17-55.

POMPA, Cristina. Religião como tradução: missionários, Tupi e "Tapuia" no Brasil colonial. Bauru: EdUSC, 2003.

PUNTONI, Pedro. A arte da guerra no Brasil. Tecnologia e estratégia militar na expansão da fronteira da América portuguesa, 1550-1700. Novos Estudos Cebrap. São Paulo: Cebrap, n. 53, 1999, p. 189-204.

. A guerra dos bárbaros. Povos indígenas e a colonização do sertão nordeste do Brasil, 1650-1720. São Paulo: Hucitec/EdUSP, 2002.

REIS, Arthur Cezar Ferreira. Prestação de contas de um governante colonial do antigo Estado do Maranhão e Grão-Pará. Revista do Instituto Histórico e Geográfico Brasileiro. Rio de Janeiro: IHGB, n. 345, 1984, p. 85-99.

SANTOS, Fabiano Vilaça dos. Feitos de armas e efeitos de recompensa: perfil do sertanista Fernão Carrilho. Klepsidra, n. 19, 2004. Disponível em http:// .klepsidra. net/klepsidra19/fernaocarrilho.htm. Acesso em 2/03/2011.

A reação dos "cidadãos" do Estado do Maranhão aos "maus procedimentos" do governador João da Maia da Gama. REUNIÃO DA SOCIEDADE BRASILEIRA DE PESQUISA HISTÓRICA, XXIV, 2004, Curitiba. Anais. Curitiba: SBPH, 2004, p. 149-55.

Pedras do ofício: Alexandre de Sousa Freire e os jesuítas no Estado do Maranhão (1728-1732). REUNIÃO DA SOCIEDADE BRASILEIRA DE PESQUISA HISTÓRICA, XXV, Rio de Janeiro, 2005. Anais. Rio de Janeiro: SBPH, 2005, p. 275-82.

SILVA, Francisco Carlos Teixeira da. Pecuária, agricultura de alimentos e recursos naturais no Brasil-colônia. In: SZMRECSÁNYI, Tamás (org.). História econômica do período colonial. $2^{\text {a }}$ edição revista. São Paulo: Hucitec/ABPHE/EdUSP/Ioesp, 2002, p. 123-59.

SILVA, Kalina Vanderlei. Nas solidões vastas e assustadoras: a conquista do sertão de Pernambuco pelas vilas açucareiras nos séculos XVII e XVIII. Recife: Cepe, 2010.

SILVA, Rafael Ricarte da. Formação da elite colonial dos sertões de Mombaça: terra, família e poder (século XVIII). Dissertação de mestrado, História, Programa de Pós-Graduação em História, Universidade Federal do Ceará, 2010.

SOUSA, Claudia Rocha de. O "lastimoso castigo e fatal estrago" das epidemias no Estado do Maranhão e Grão-Pará na primeira metade do século XVIII. Monografia de graduação, História, Faculdade de História, Universidade Federal do Pará, 2011.

VIEIRA JR., Antonio Otaviano. Entre paredes e bacamartes: história da família no sertão (1780-1850). Fortaleza/São Paulo: Demócrito Rocha/Hucitec, 2004. 